\title{
الأدبُ الإسلامي وفاعليةُ سلطة المركز \\ بين دلالتي التوصيف والتوظيف
}

فارس عبد الله بدر الرحاوي"*

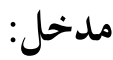

الأدبُ الإسلامي هو أحد تلك الخطابات، التي تمتلـــك فاعليتَهــا، وقـــــتها في

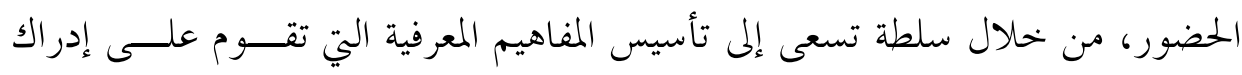

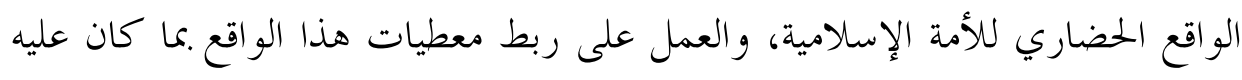

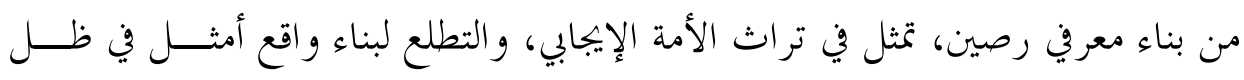
ظروف الفوضى الحضارية التي يعيشها العالم.

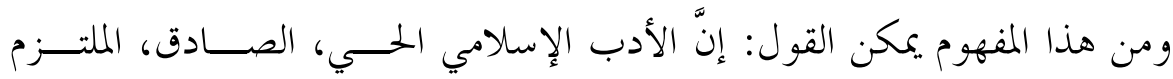

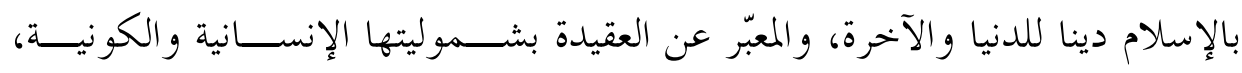

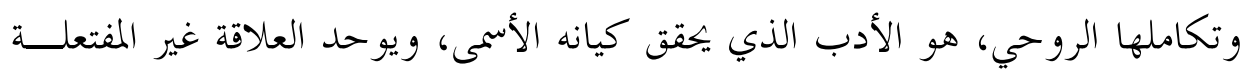

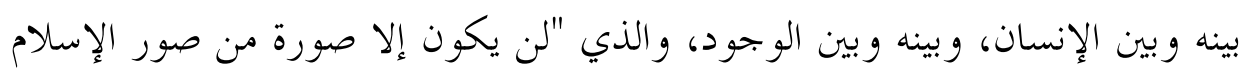

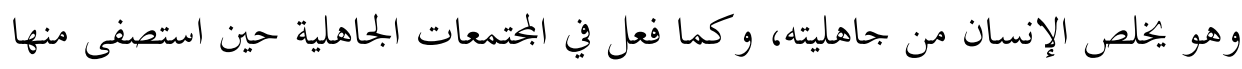

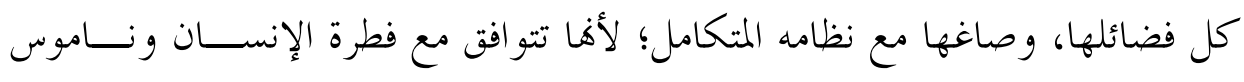

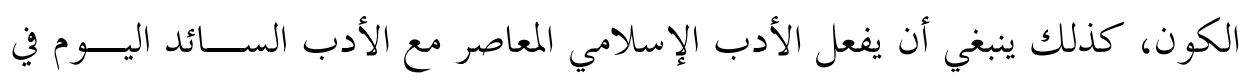

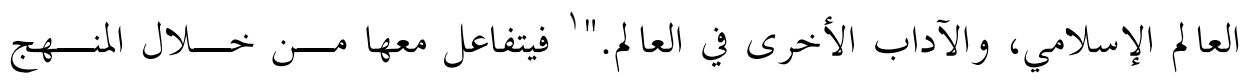

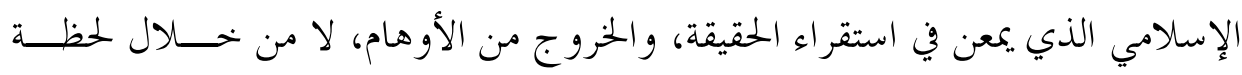
الإعجاب الزائلة أو العابرة هذذه الآداب.

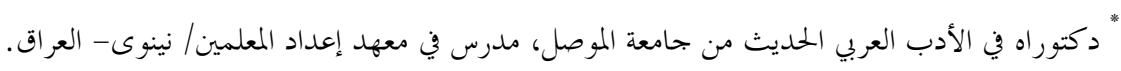

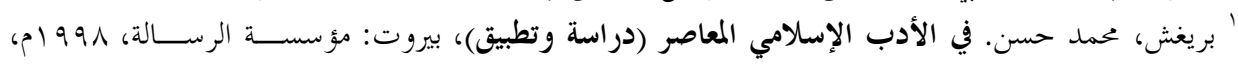




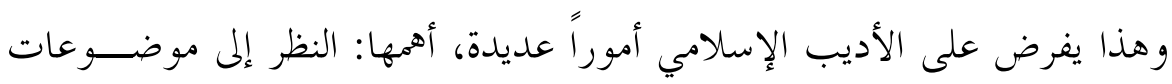

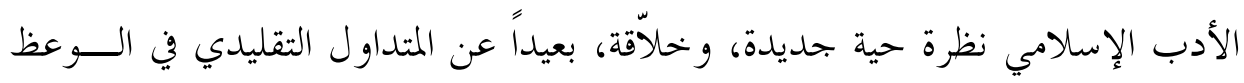

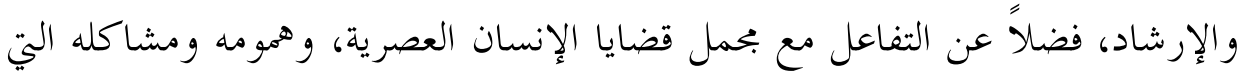

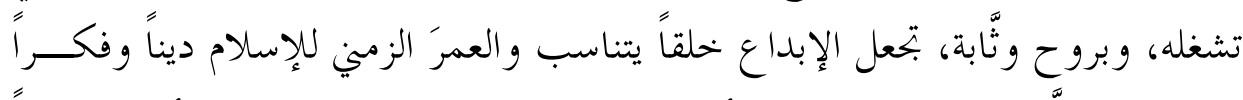

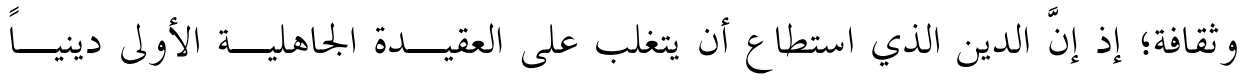

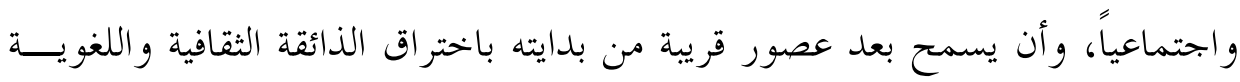

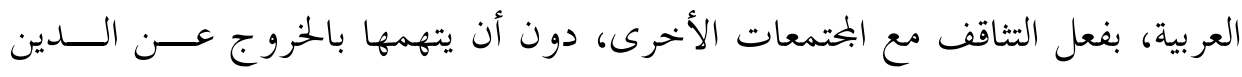

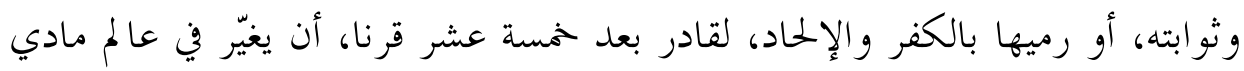
ما لم تستطع المادية الوضعية أن تغيّره.

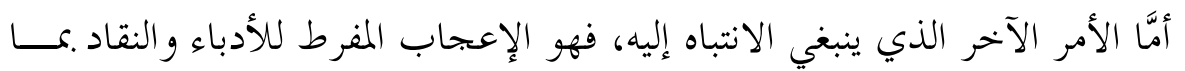

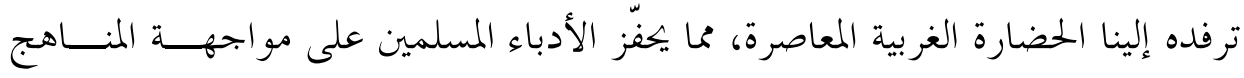

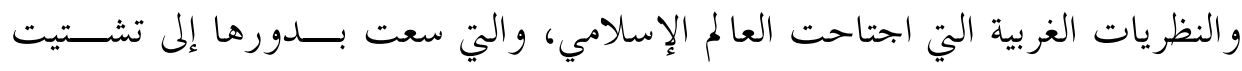

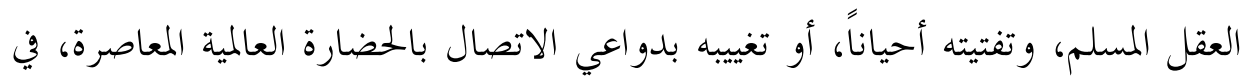

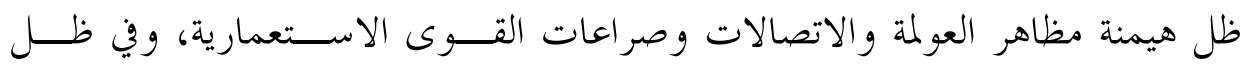

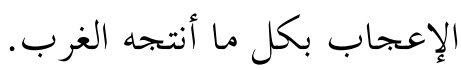

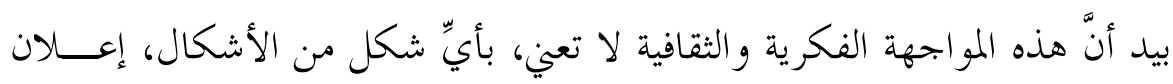

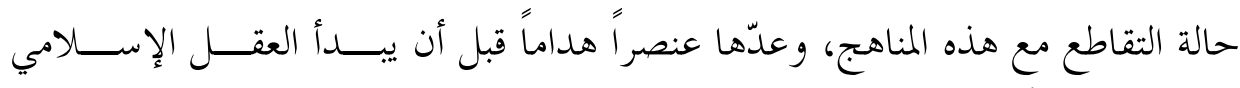

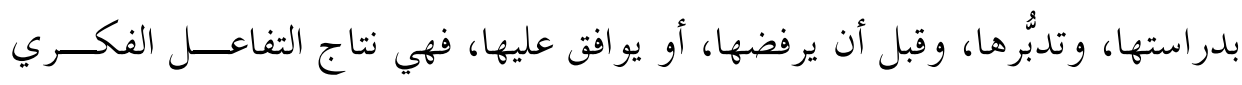

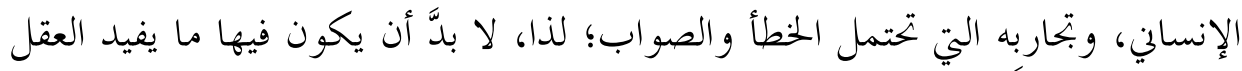
الإسلامي، ولو كان الأمر بحدوده الدنيا.

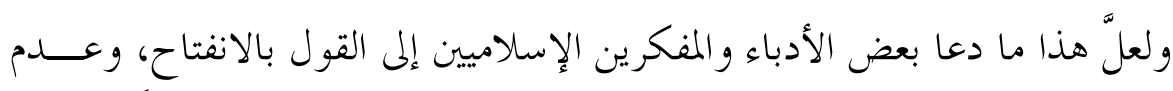

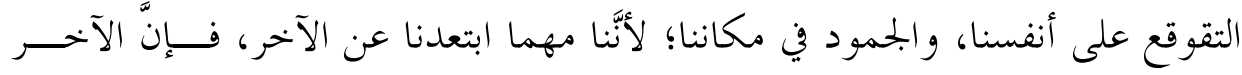

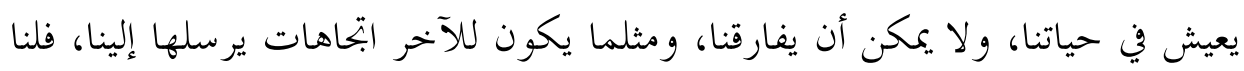

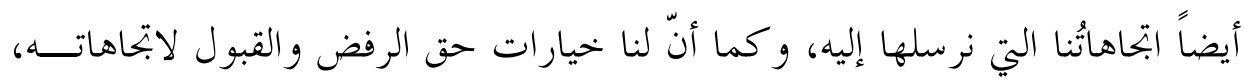




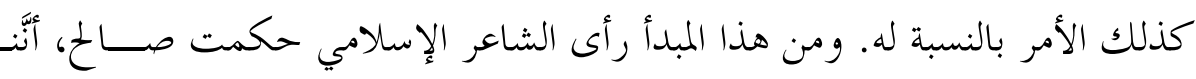

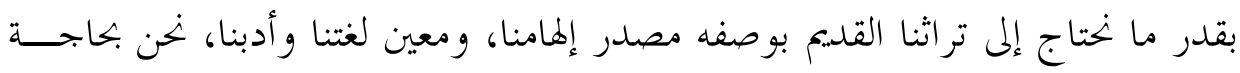

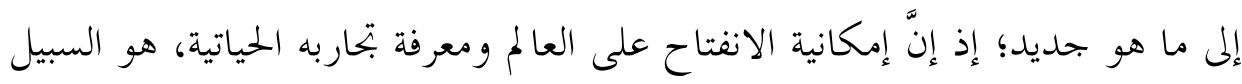

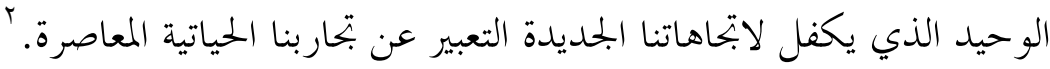

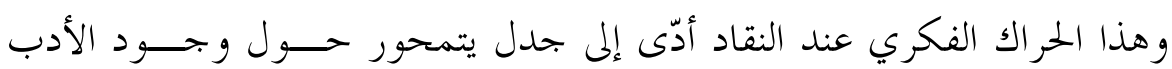

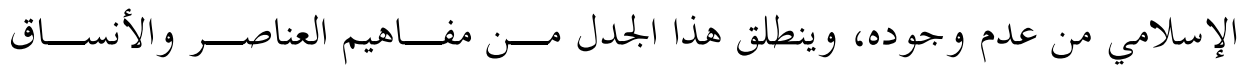

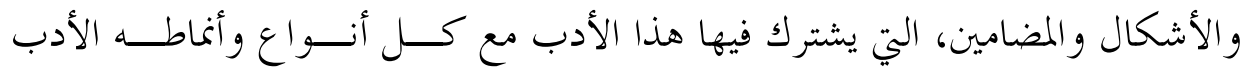

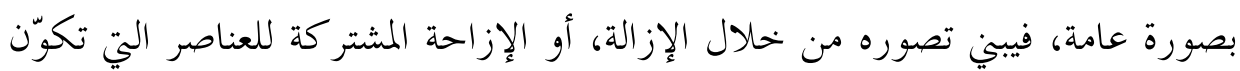

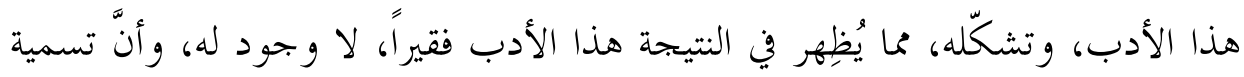

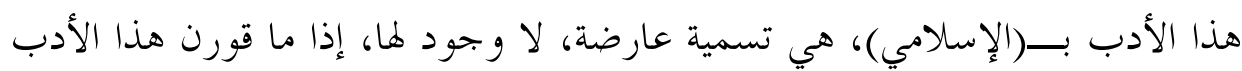

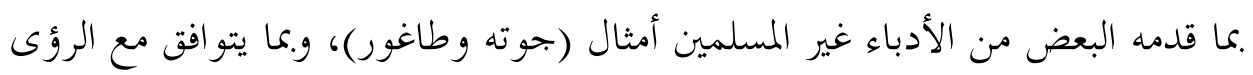

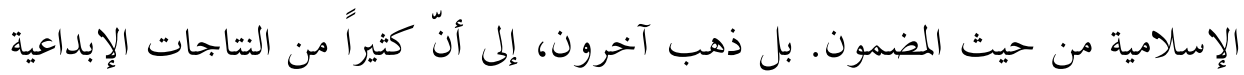

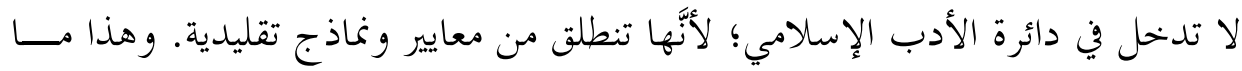

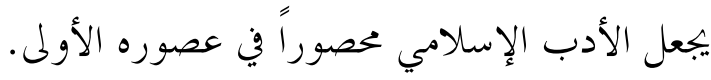

ولحل هذه الإشكالية، من حيث التسمية والوجود، وبغية تثبيت رؤية حقيقيسـة في

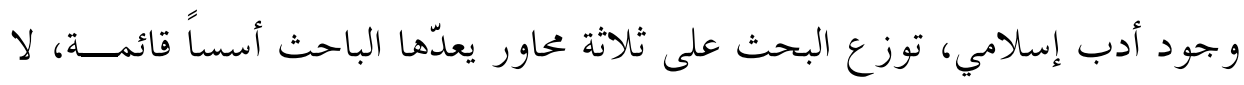

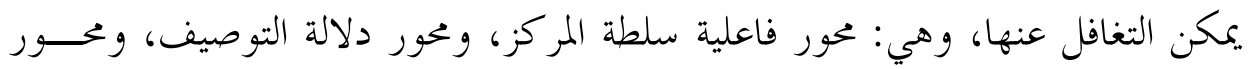

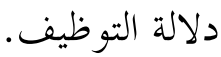

\section{أولاً: فاعلية سلطة المركز}

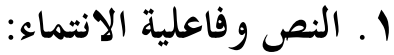

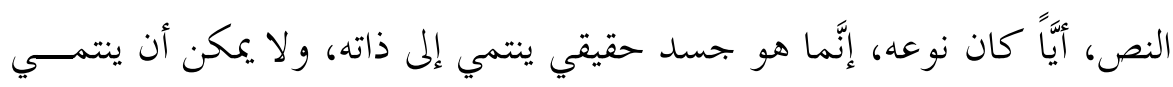

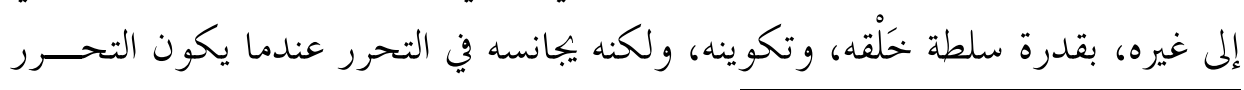

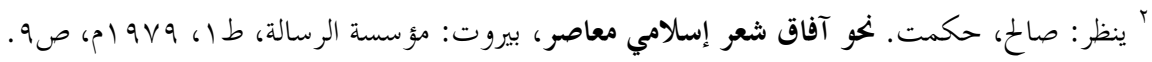




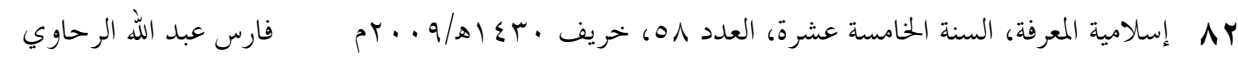

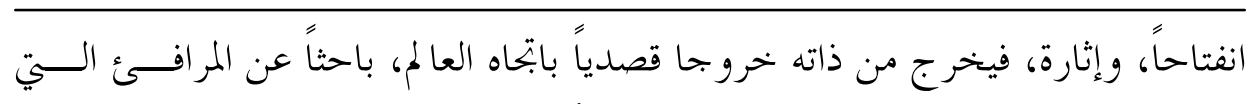

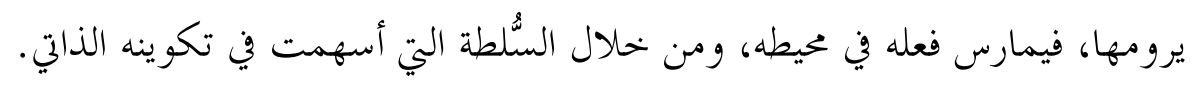
لذا، ومن مفهوم هذا الانتماء، يمكن القول: إنَّ فاعلية السلطة وقوها التي تخلــق هذا النص هي التي تحدد ماهيته وعنوان هويته. فعندما يدافع الأدباء الإسلاميون بأدهمم

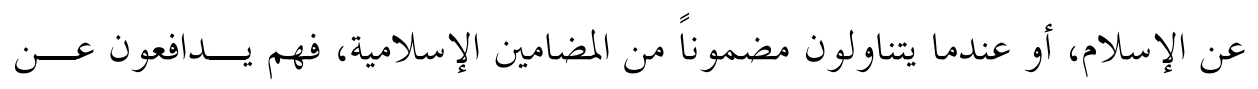
انتمائهم الذاتي المتحقق في أعماق النفس والذات المؤمنة هذا الانتماء، وهو في حقيقته انتماء عقدي، روحي وفكري، يعبّر عن صدق الإيمان وأحاسيس الذات المسلمة. ومن هنا، فإنَّ سلطة المركز، من وجهة نظر الباحث، هي سلطة توجد في ككل

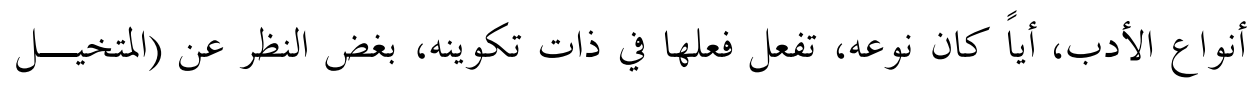
الإبداعي)، الذي تصنعه المخيلة، وهو الفعل الناجز من صنع خخيلة الأديب واستخداماته

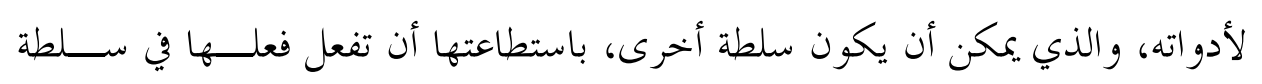
المر كز

لذا، فإنَّنا نرى أنَّ سلطة المركز هي سلطة موضوع وليست سلطة مخيلة، بوصف

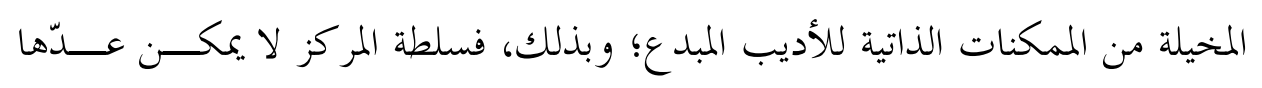

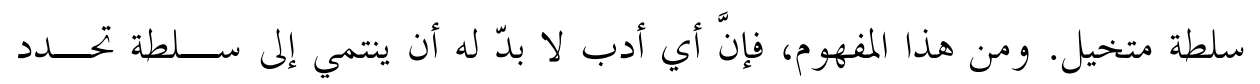

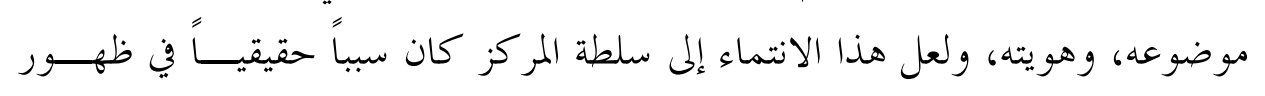

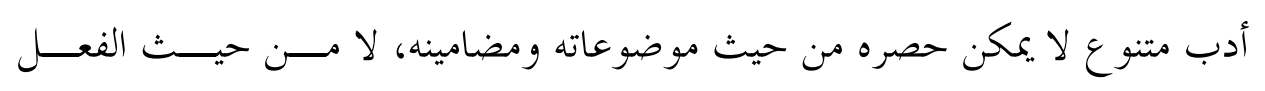
الإبداعي المتجسد بفعل المتخيلة.

إنَّ سلطات المركز متعددة بتعدد المضامين، لا بتعدد الأشكال و القوالب والأنماط،

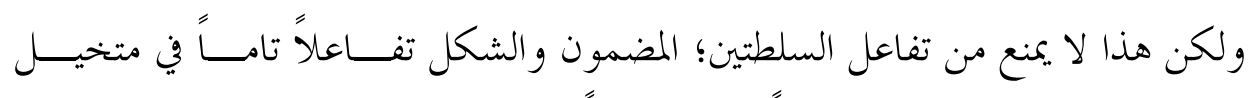

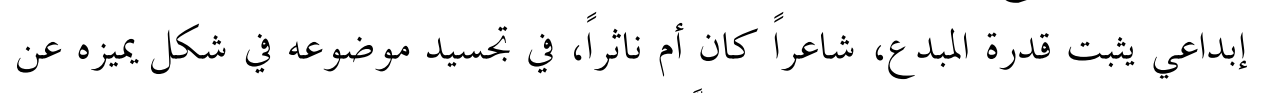

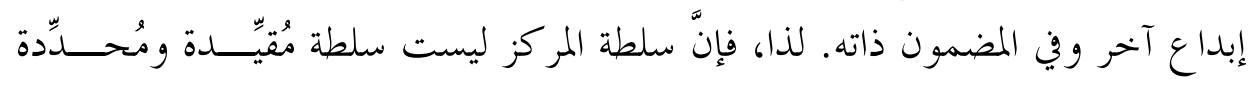

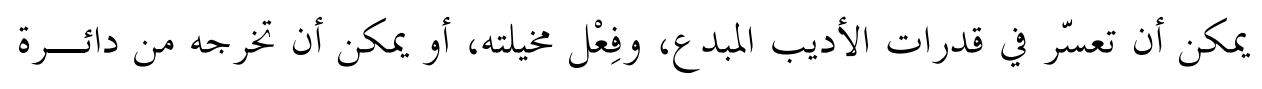




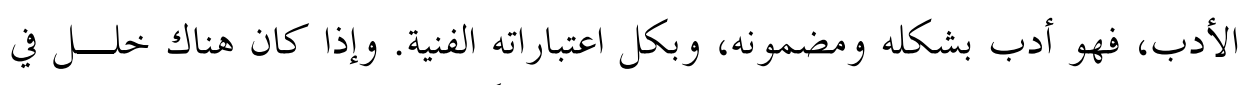

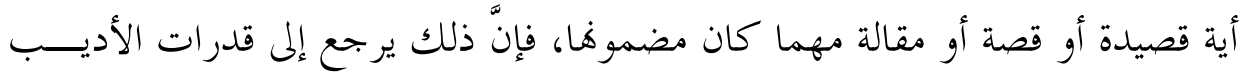

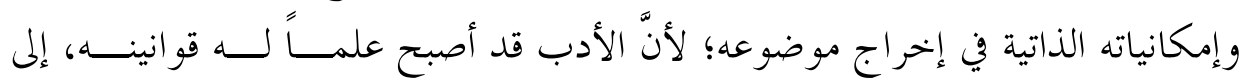

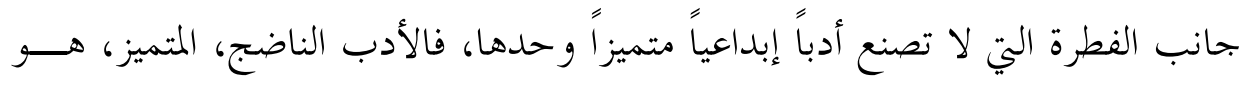
صناعة فنية لمضمون خام.

إنَّ سلطة المركز في الأدب الإسلامي هي سلطة وجود العقيدة الإسلامية في هــــا

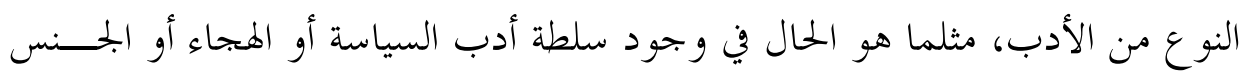
أو الإلحاد، أو الغزل، إلخ.

وهذا، هو الأدب الإسلامي، حين يبحث في مرافئ الآخر، يكون نصاً وخطابًا

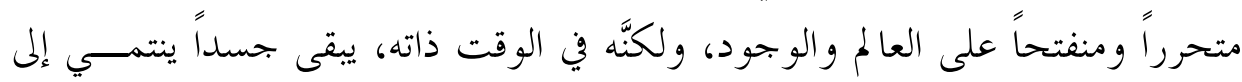

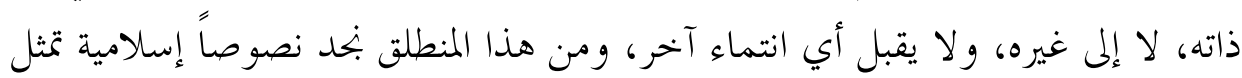

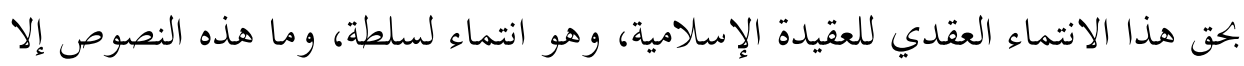

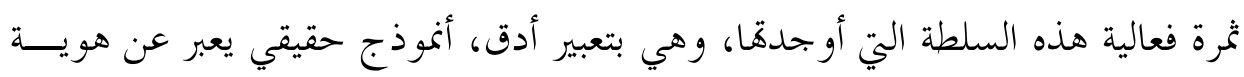
المنتمي لهذه السلطة، و المؤمن هـا إيماناً حقيقياً.

ولعلنا نتلمس صدق هذا الانتماء من خلال نصوص بعض الشعراء الإسلاميين من

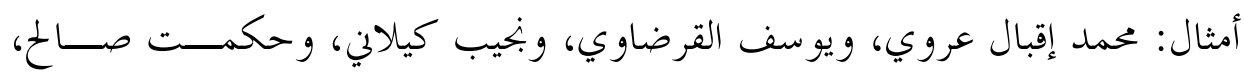

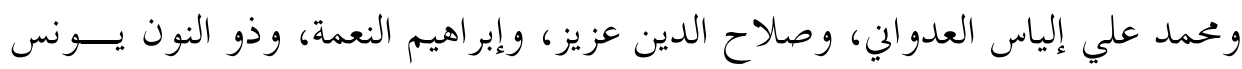
مصطفى، ومحمود مفلح، ومحمد منلا غزيل، ومحمد بنعمارة، وغيرهم كثير. فمما يقوله الشاعر حكمت صالح في قصيدته (السهو عن الــــات في محاريــبـ

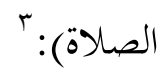

$$
\text { إنَّها رُوَحِي. }
$$

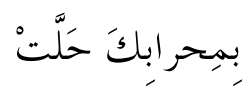

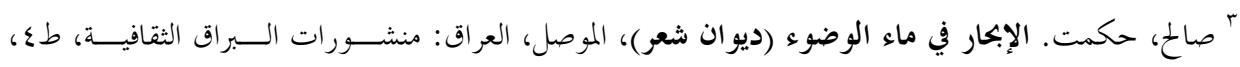




$$
\begin{aligned}
& \text { ربَّمَا يَعْكفُ قَبلي } \\
& \text { للصنانة } \\
& \text { جَذَبَتْني قِبْلَة } \\
& \text { أَسْهُو بِهَا عَنْ كُلِْ مَا حَوْبِي } \\
& \text { وَيسنهُو الإنْتِبَاهْ } \\
& \text { وَحَشَاشََاتِي انْتَضَتْني أَرَقَاً } \\
& \text { يَحْجُبْ طَرْفِي } \\
& \text { بَجَلََل لَنْ أَرَاه } \\
& \text { وَانْبْهَاري... }
\end{aligned}
$$

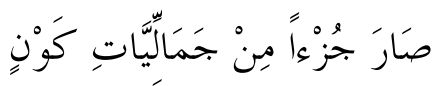

$$
\begin{aligned}
& \text { ضَاقَ عَنْهُ مُحْتَوَاهْ }
\end{aligned}
$$

أما الشاعر الإسلامي محمود مفلح، وهو من فلسطين، فإنَّنا نلمح إصراره وثباتــــ على العقيدة الإسلامية في قوله:

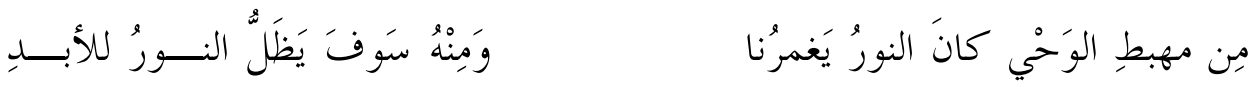

$$
\begin{aligned}
& \text { أما الشاعر الإسلامي صلاح الدين عزيز وهو من العراق، فقد كانت قصيدته }
\end{aligned}
$$

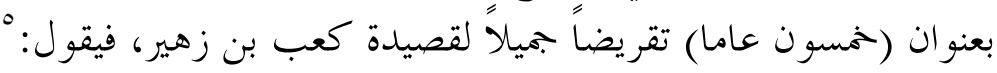

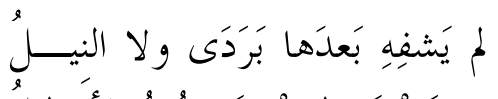

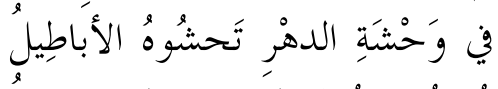

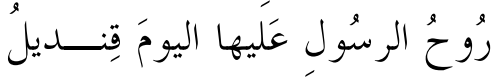

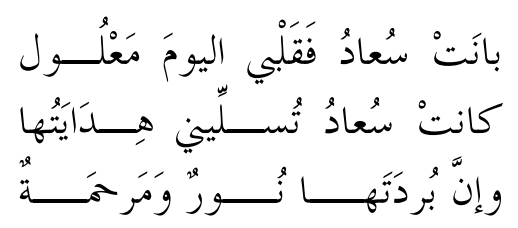


إنَّ عمق الأصالة التي يمتاز بها الشاعر الإسلامي تبدو من خهالال تمسكه بالعقيـــدة الإسلامية، وتفاعله مع كل حدث له مساس هذذه العقيدة، والشاعر الملتزم بذذه العقيدة

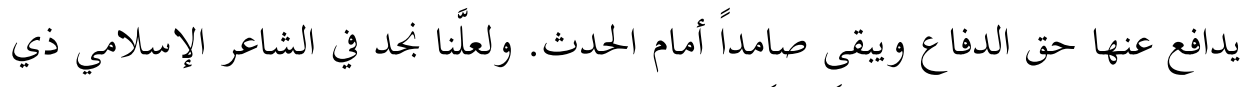

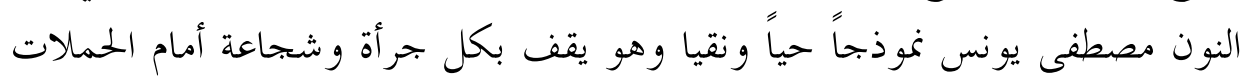

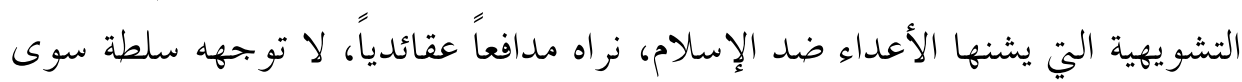

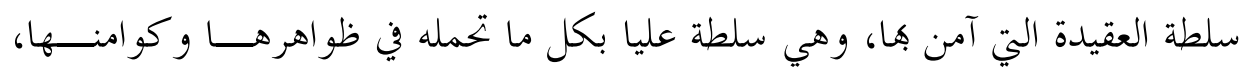
وهي السلطة العليا للأدب الإسلامي. لقد تفاعل ذو النون مصطفى مع أهم وأكبر حدث معاصر واجهـــهـ المســلمون،

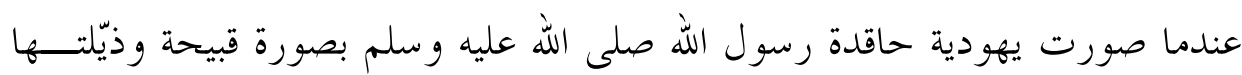

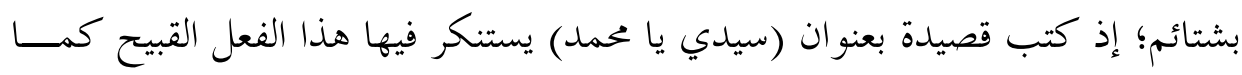

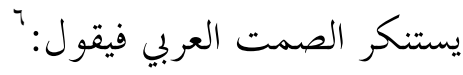
جَسَدُكَ الممتدُ بَيْنَ المحيطين

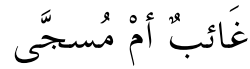

$$
\begin{aligned}
& \text { سَيِّي - يا مُحمَّدُ - أعيُها الوَطنُ الشجِيّ } \\
& \text { أيَّها الذكرَى الدَامعَة }
\end{aligned}
$$

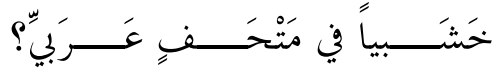

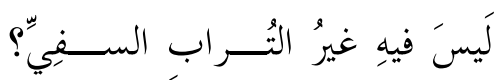

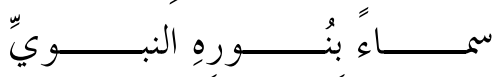

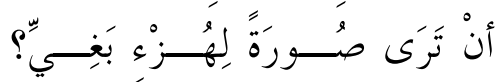

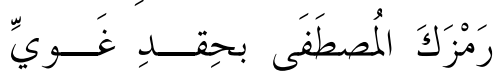

أَيُها السيفُ كَيفَ أصبَحْتَ سَيفاً

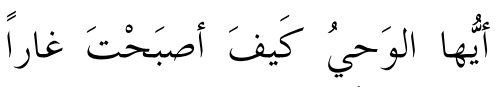

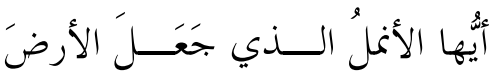

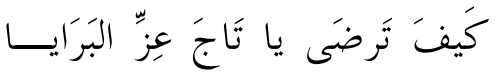

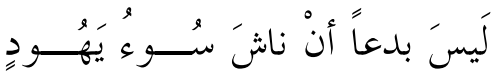

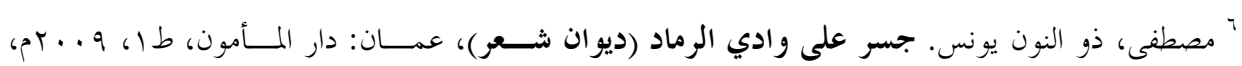




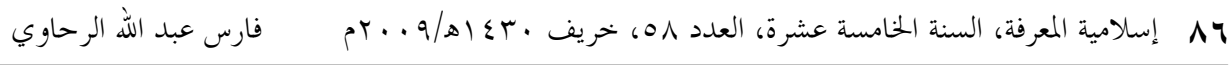

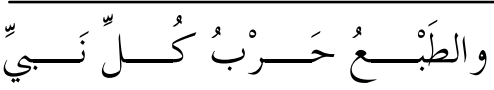

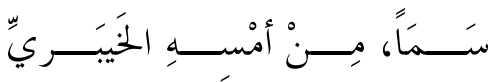

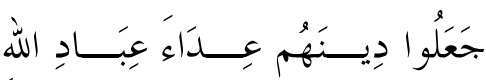

إنَّهُ الوترُ يَستَقِي مِنْ ذُرِّى التاريخ

إنَّ هذا الثبات و التمسك بالعقيدة الإسلامية بوصفها مركز سلطة هذا النوع مــنـ

الأدب، جعله أدباً ملتزماً، "يتحرك الإسلام في توجيهاته الأساسية و التفصيلية.... إنَّـــه.

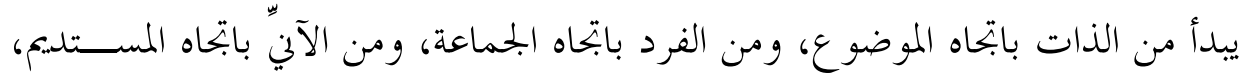

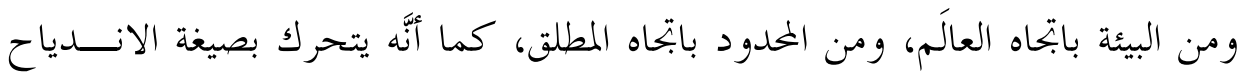

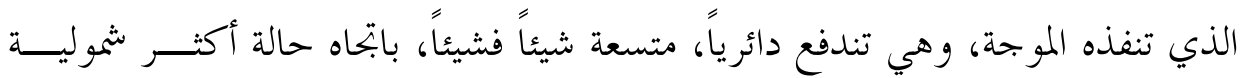
وامتداداً.

إنّ سلطة الخطاب في الأدب الإسلامي هي الإسلام؛ روحهــاً وجســــاً، مركــزاً

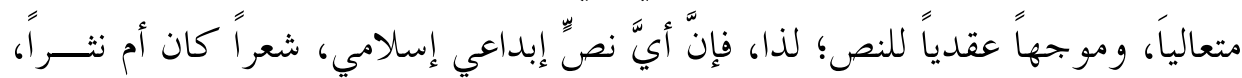

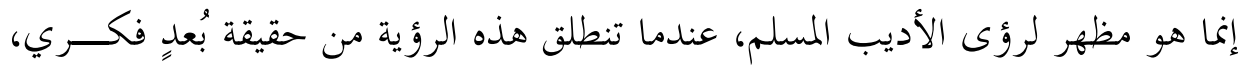
وتصوريٍِ يرى الإسلام ديناً شمولياً فيما يخص الإنسان و الوجود و وكل شيء فئ في الحياة،

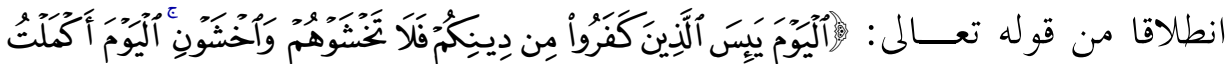

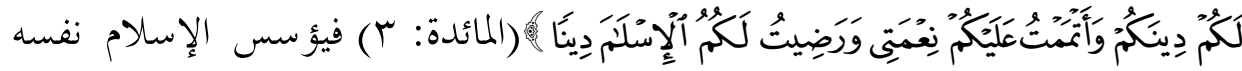

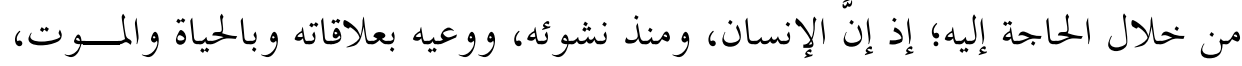
و الكون و الوجود، كان "في حاجة إلى عقيدة تعمر قلبه، عقيدة تفسر له الحياة وتربط

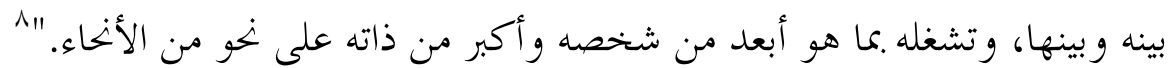

\section{Y. ب. النص وفاعلية سلطة المركز:}

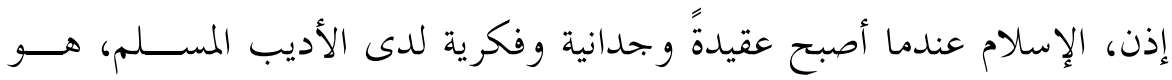

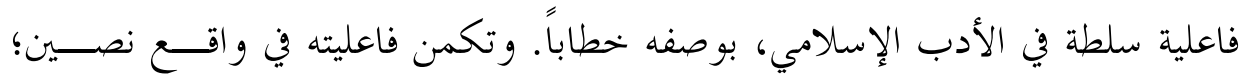

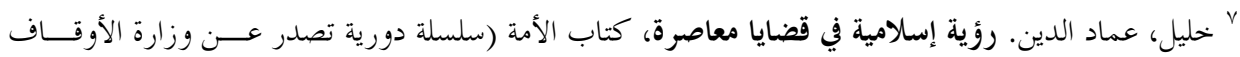

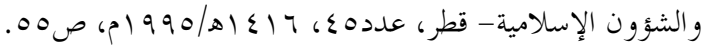

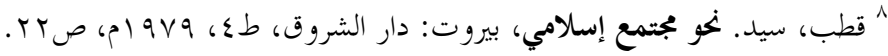




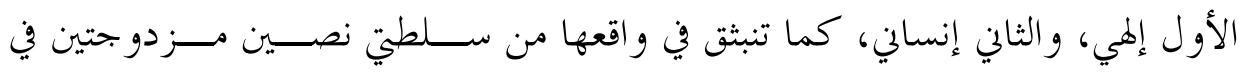

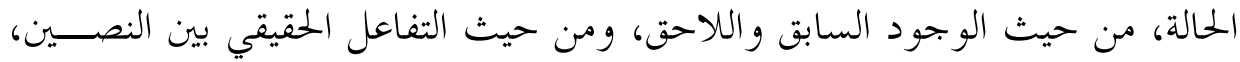

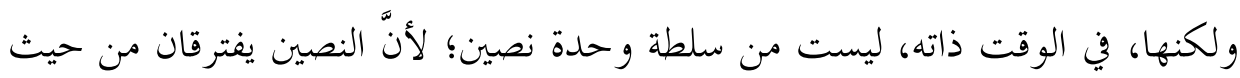

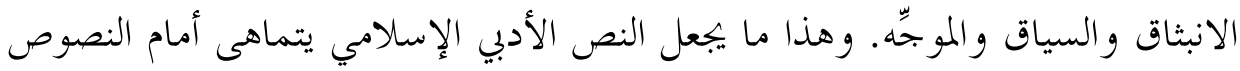

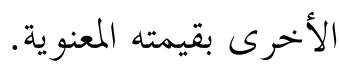

إنَّ حقيقة سلطة النَّص الأول هي سلطة المركز (الإسلام) بالإيحاء، والمتمثلـــة في

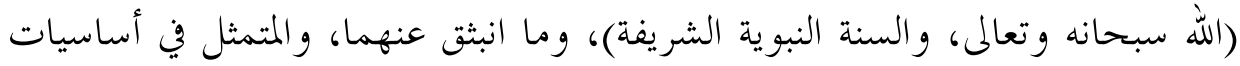

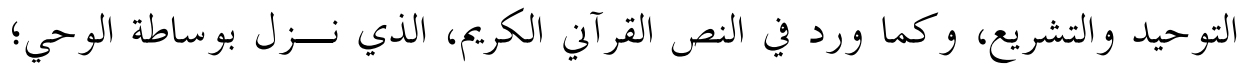

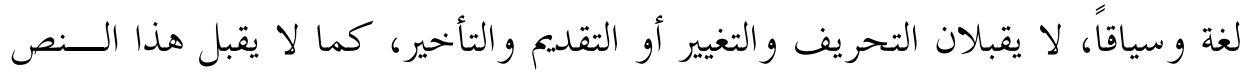

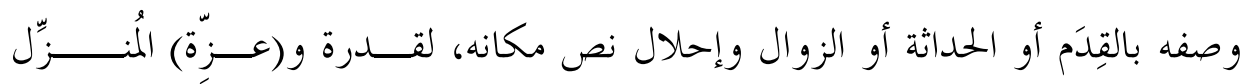

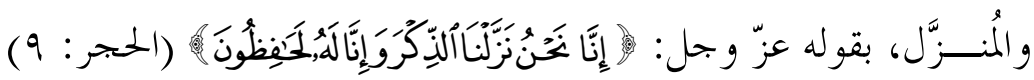
يمكننا القول: إنَّ النص القر آني الكريع، ومنذ نــزوله، كان يجيب "عــن أســــلة

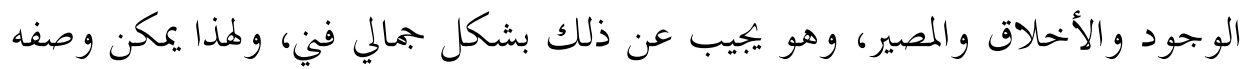

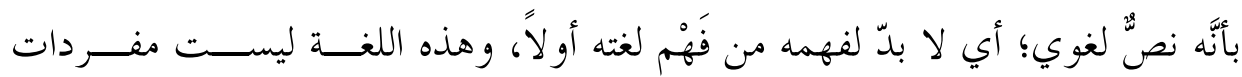

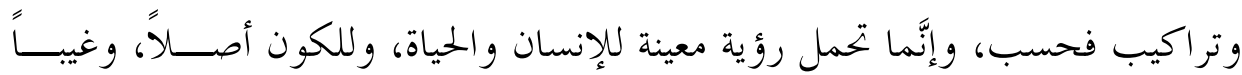

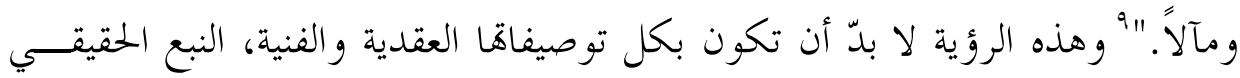

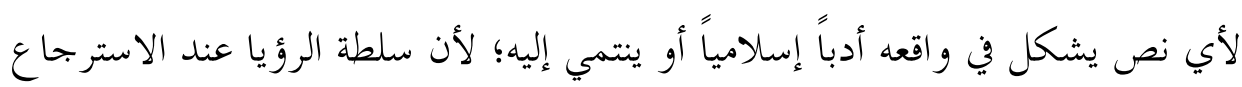

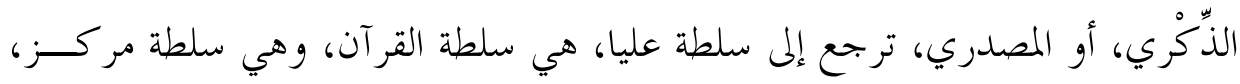

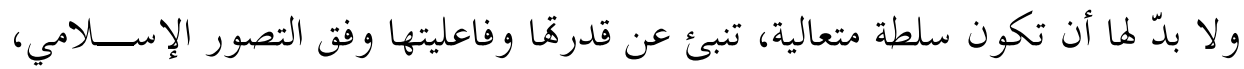

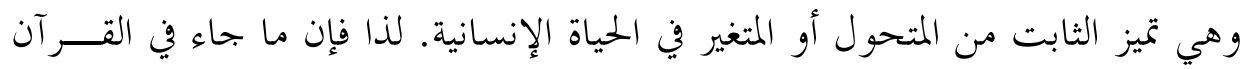

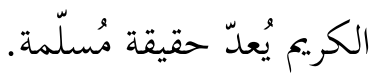




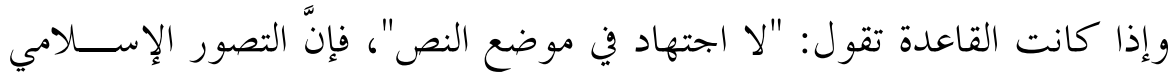

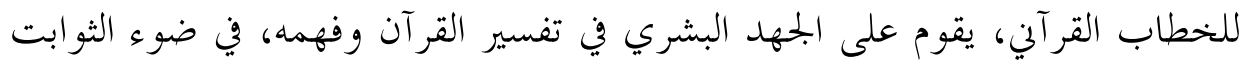

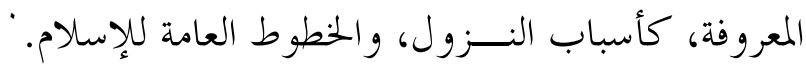

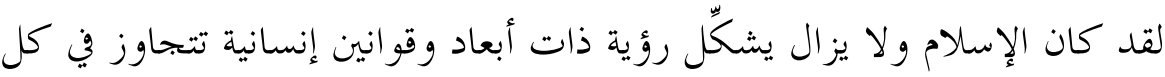

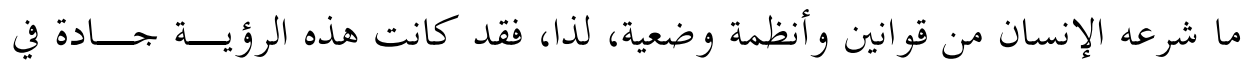

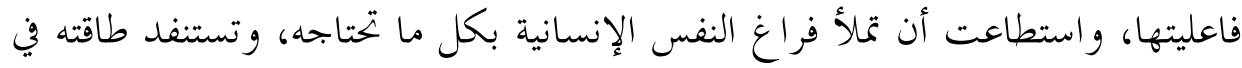

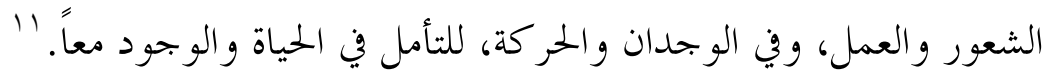

ومن هذا المنطلق، فإن مراجعة نقدية وتحليلية للنتاجات الإبداعية الإسلامية، الــتي

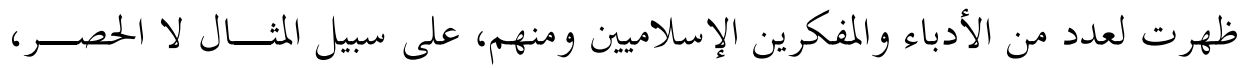

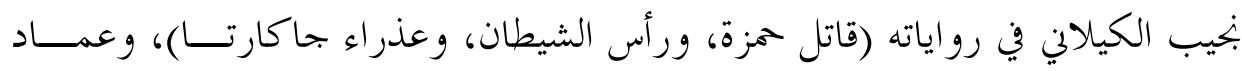

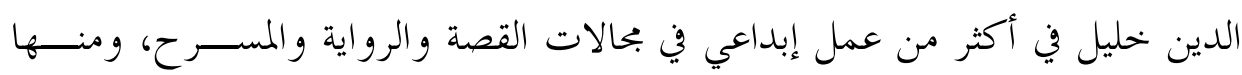

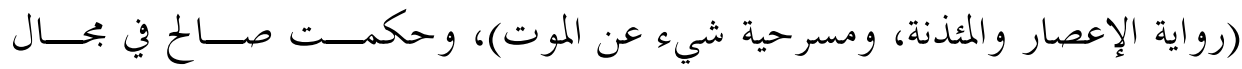
الشعر، ب' ومحمود شيت خطاب الذي بقيت بحموعتاه (عدالة السماء وتدابير القــــر )

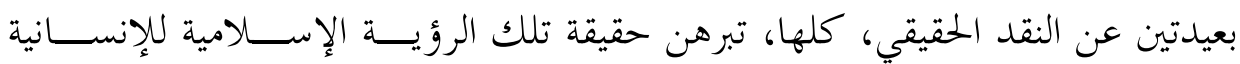

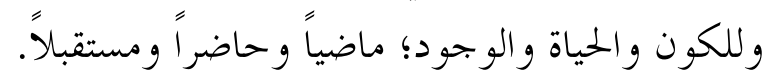

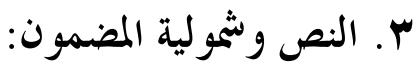

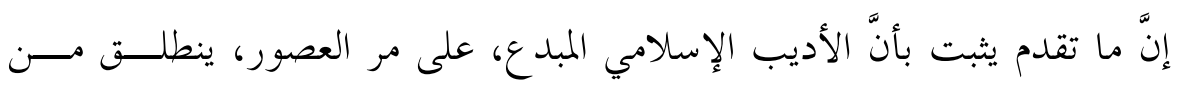

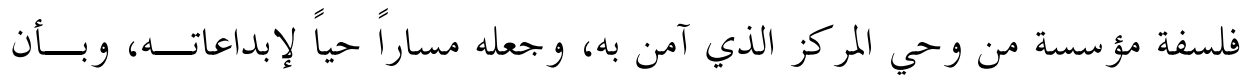

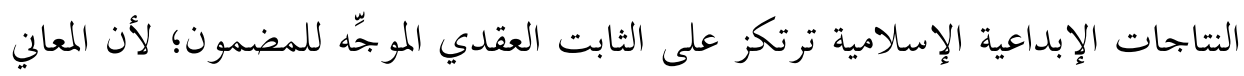
' ' المناصرة، عباس. مقدمة في نظرية الشعر الإسلامي، عمان: دار البشير - بـيمروت: مؤسســة الرســالة، طا،

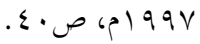

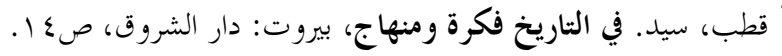

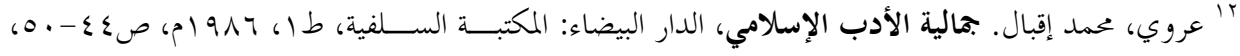

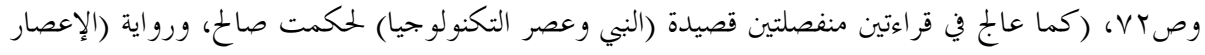
والمئذة) لعماد الدين خليل. 
المقصودة في الأدب الإسلامي مؤسسة على محددات العقيدة الإسلامية، غير خحارجـــة عنها؛ وهذا يعني أن العقيدة هي الحقيقة الأكيدة التي لا يختلط فيها الشك باليقين.

ولنا أن نتلمس هذا الثابت العقدي في نموذج من أدبنا الإســلامي القــــيم، وفي

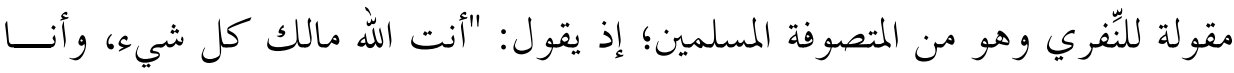

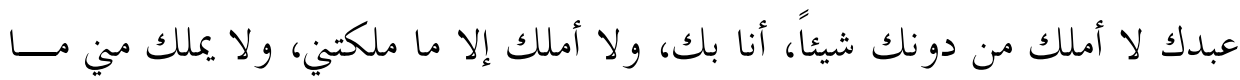

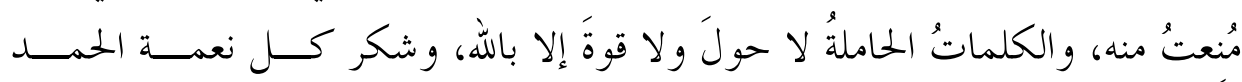

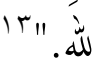

إنَّ هذا الثابت العقدي في أدب النفري وغيره من المتصوفة أمثال محي الدين بــن عربي والحلاج وغيرهما، ما هو إلا من قبيل استمرارية امتلاك هاجس السؤال، والسئ ال

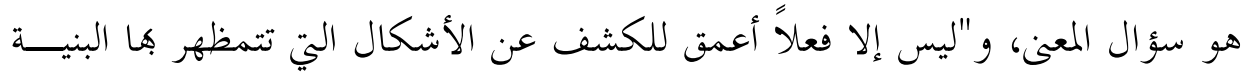

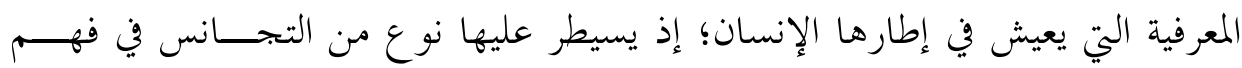

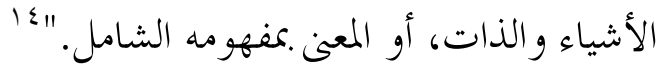

لقد كان الأدبُ الإسلامي، ولا يزال، بكل مضامينه إنسانياً وشثمولياً لاعتبــارات

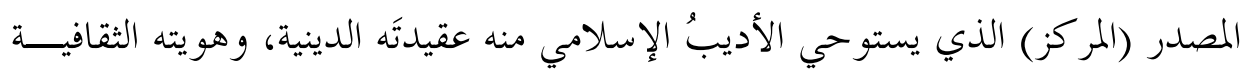

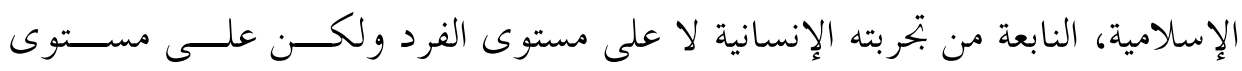

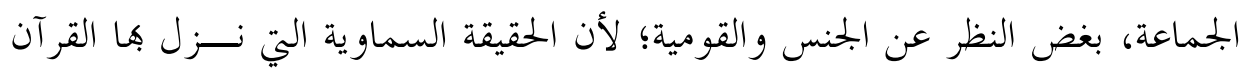

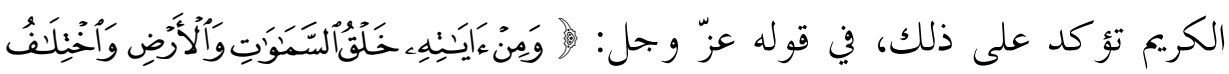

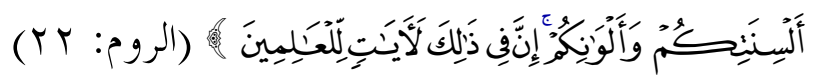

ومن التجارب النموذجية الحية والجحديدة في أدبنا المعاصر تجربة الشاعر الإسلامي

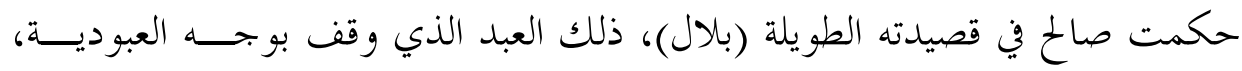

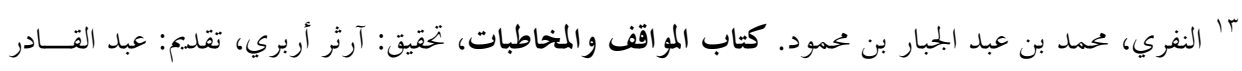

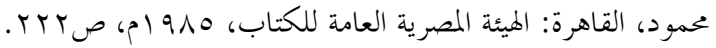

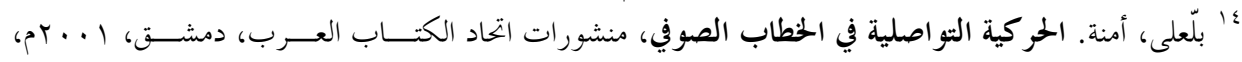




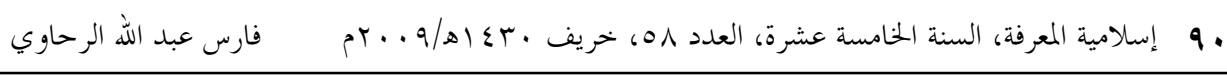

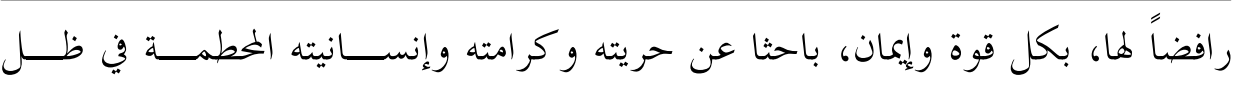
استغلال القوي للضعيف، و الغني للفقير، فيقول الشاعر، وعلى لسانئ لسان بلال: هَتَفَ الصَوتُ بِهِ مِنْ لَجْلَجَاتِ النَفسِ.... يا إنسانُ، هَلا ثنارَ بُر كانُ تَمَنّى ثورة" م تَنْتَفُْ الأعر افَ في ذا البَلَدِد...

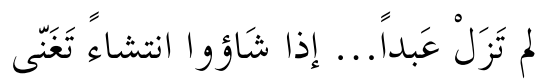

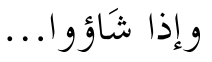
فلا تملكَ مِنْ شَدْوِ كَكَ لَحَنْاً. ... هَتفَ الصَوتُ لِغيرِ المَرَّة الأولى ألا أبحثثُ عَن إلهٍ يَقطعُ الأغْلال....

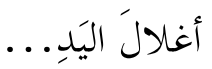
وفي مقطع آخر يقول بلال: أنا زبخيّ

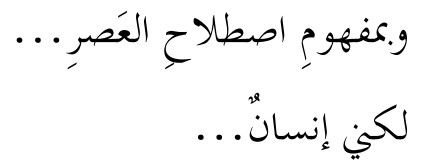
بروحي وَفِكري بضَميرِي.... وَبَلَونِي الأَنْو سِي،

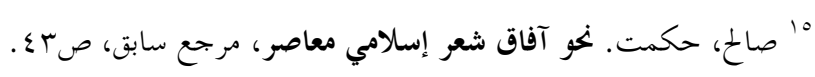




$$
\begin{aligned}
& \text { إن فرضي رافض رَفضِي... }
\end{aligned}
$$

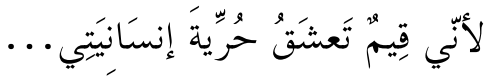

ولعلَّ ما ذهب إليه الشاعر محمد بنعمارة، في سبب إنسانية الأدب الإسلامي كان

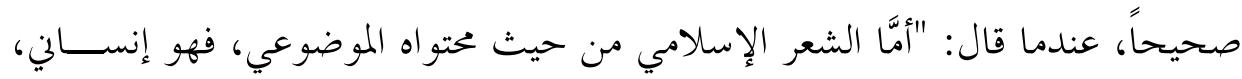
يخاطب في الإنسان سموه، ويركز على إضاءة جانب القدرات الإيجابية فيه، التي تنسجم

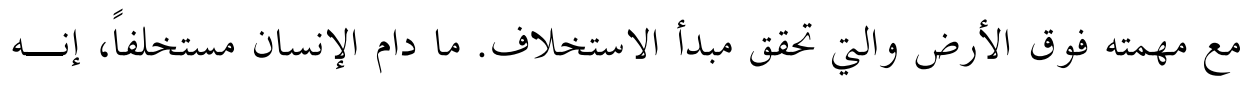

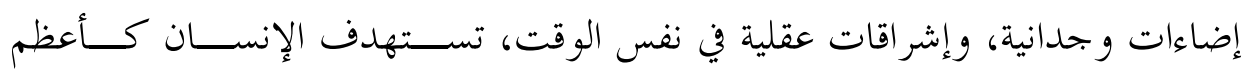

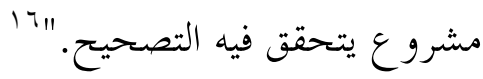

ومن هنا يمكن أن نفهم، أن حقيقة التصور الإسلامي للمركز هي حقيقة ثابتة لا يمكن لها أن تغادر العقل المسلم المبدع، لا في سلو كه ولا في أدبه.

ثانياً: دلالة التوصيف

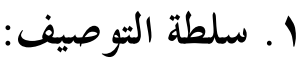

نعتقد أنَّ مسألة توصيف هذا الأدب بـــ(الإسلامي) لا يمكن إز التها، و لا يمكــنـ

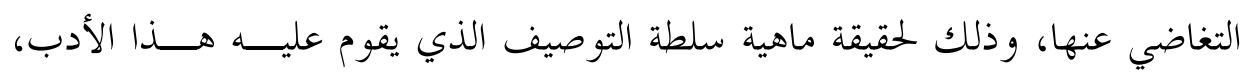

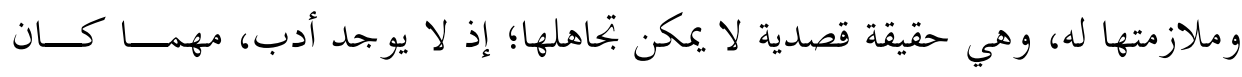
نوعه، واتجاهه، لا يحمل في كل مقوماته الخارجية و الداخلية قصدية وجودهه، وقصـــدية

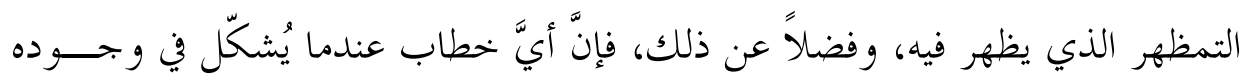

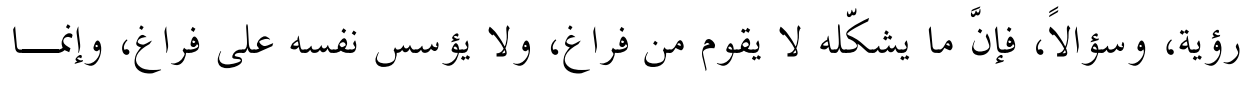

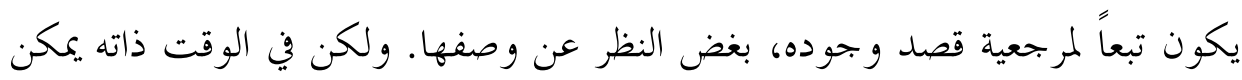

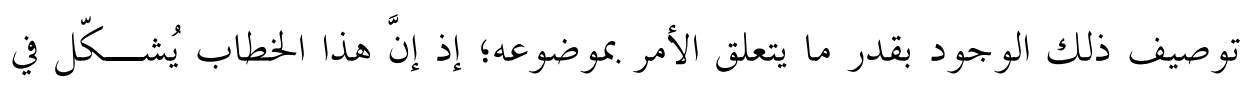

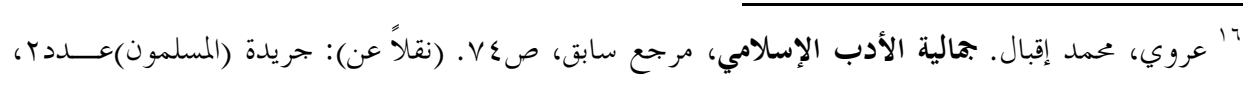




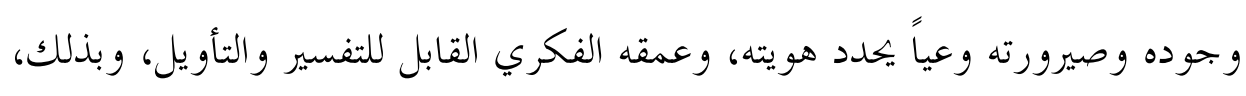
فهو بحد ذاته صيرورة وجوده النّي المختلف عن صيرورة أي نص آخر. فالشاعر الإسلامي حكمت صالح يقول في قصيدته (النبي وعصر التكنولوجيـا)

$$
\text { وهي من روائع الأدب الإسلامي: الإسي }
$$

وَ(بِدارِ الندوَةِ) المغروز

في مِحْجَرِ تاريخَ العُصور

قِيلَ: يا مُعشرُ قد أبنجبتِ الدُنيا غُلاماً

سَوَتَ يبتزٌُ الظلاما

$$
\begin{aligned}
& \text { بِسيوفٍ مِنْ زجاج القَزح البَارق } \\
& \text { في أفقِ المصِير } \\
& \text { يَحِمِل الأرضَّ عَلى رَاحَتِه } \\
& \text { يَخرُجُج الناسُ مِن الظلمةِ للنُور } \\
& \text { ألا يا قورُ قَد حَانَ النُشُور }
\end{aligned}
$$

إنَّ إمكانية التأمل و التمعن في هذا النص تُظهر، وبوضوح تام، قصــيدة الشـــاعر

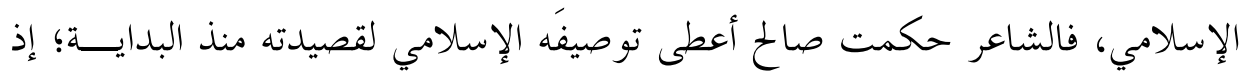

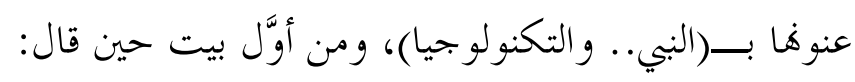

$$
\begin{aligned}
& \text { أحقابًا تو التْ فيها أحداثٌ جسَام } \\
& \text { إنَّ في الأرض الحجازيةِ.. في(مكة) }
\end{aligned}
$$

ففي هذه القصيدة ظهرت تداعيات الذاكرة الإسلامية لدى الشاعر بوضوح مـــن

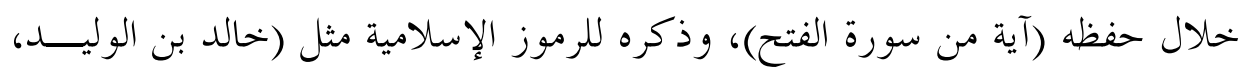

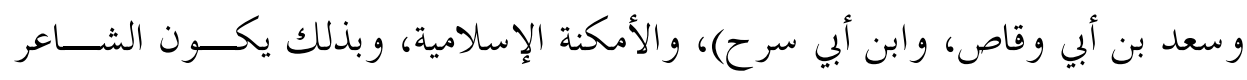




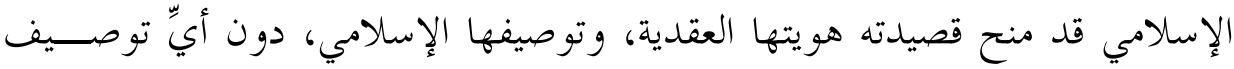

إنَّ مسألة توصيف الأدب بــ(الإسلامي)، لا يمكن أن نعدّها مسألة طارئة علـى ألـى

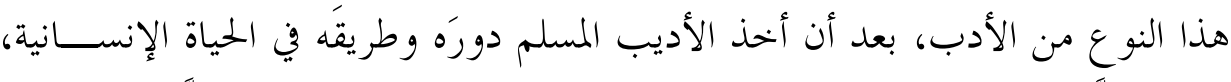

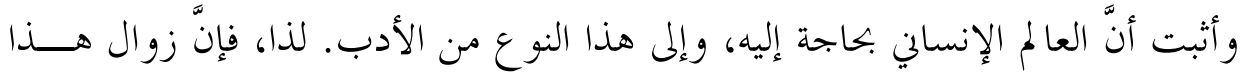

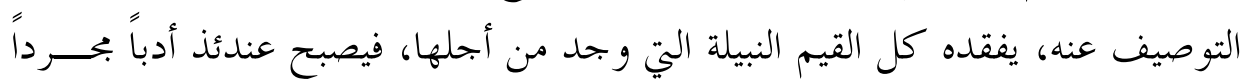

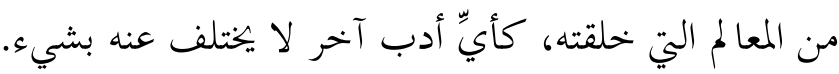

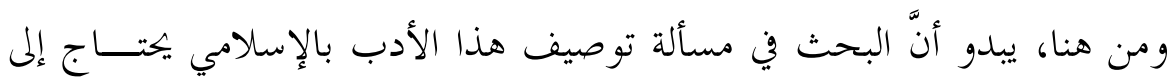

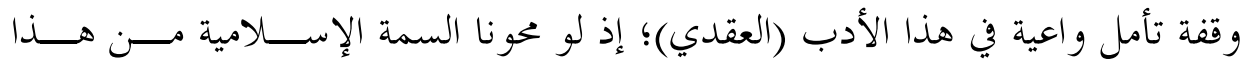

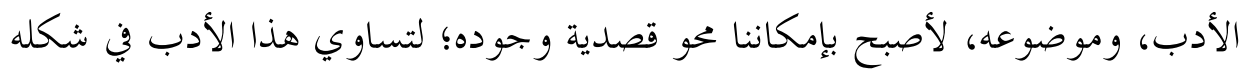

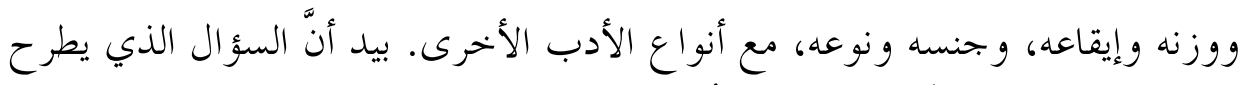

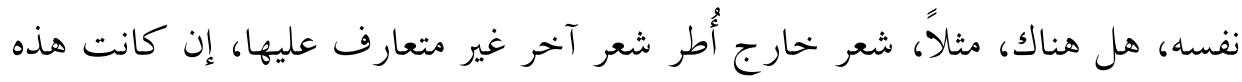

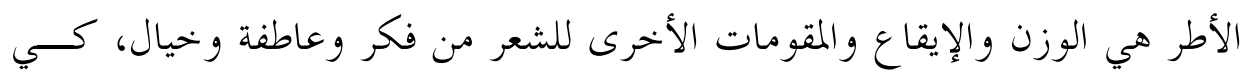

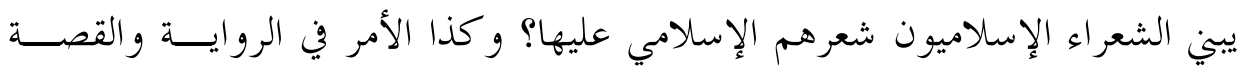

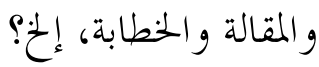

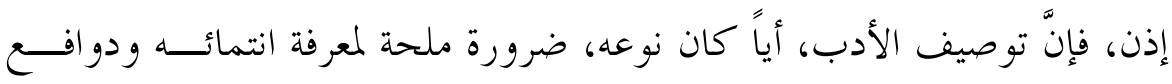

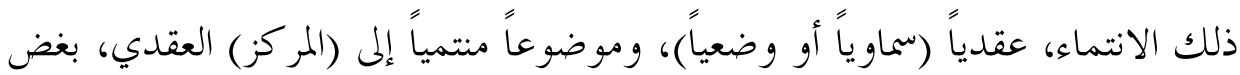
النظر عن إمكانية قبوله أو رفضه، بوصفه نتاجاً إبداعياً يمثل ذلك الأن الانتماء.

\section{r. سلطة المعيار:}

يمكن القول: إنّّ التوصيف للأدب الإسلامي يعبّر عن الرؤية الإسلامية التي ينطلق

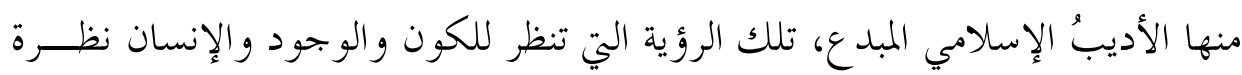

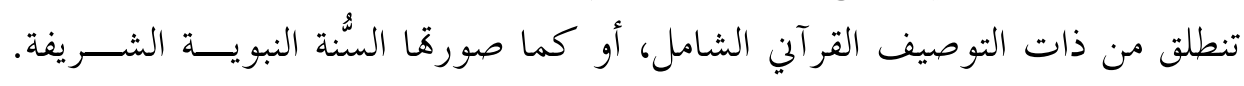

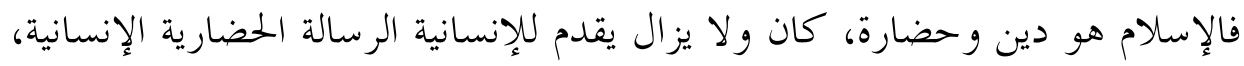




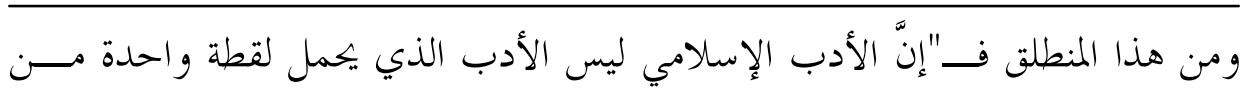

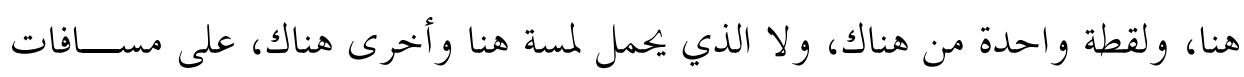

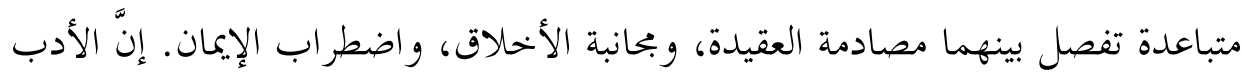

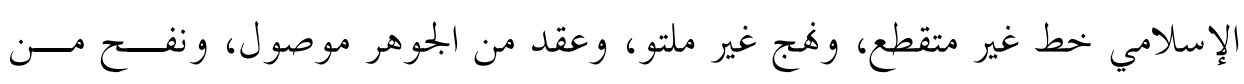

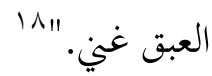

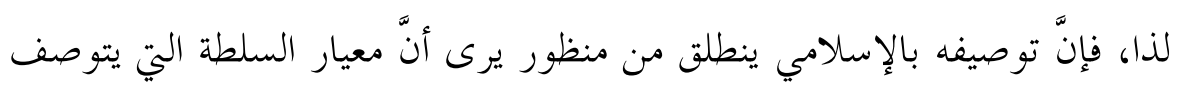

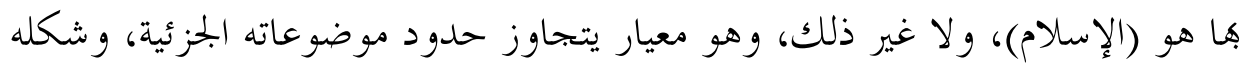

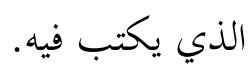

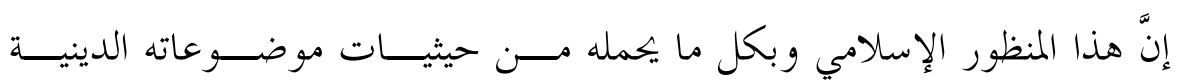

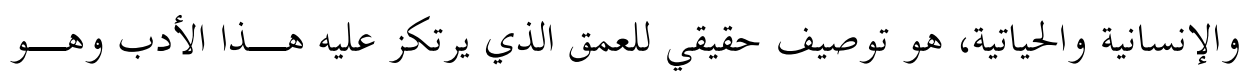

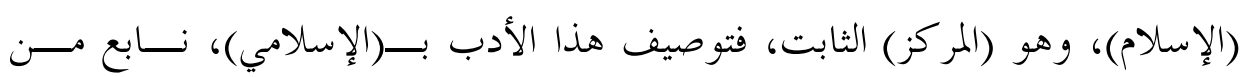

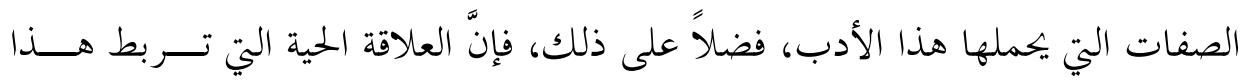

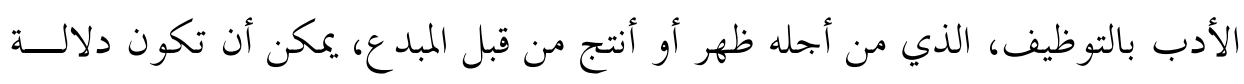

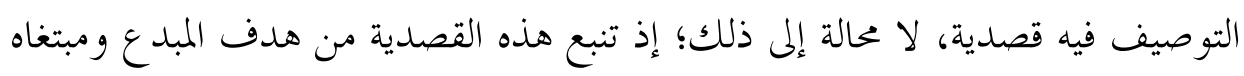

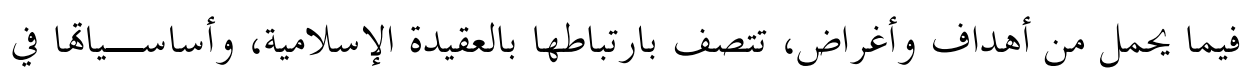

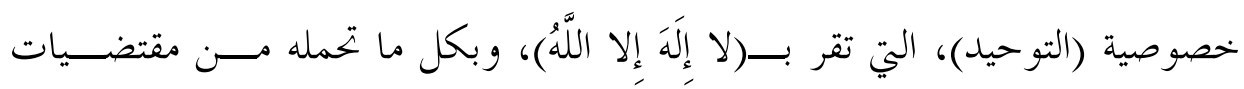

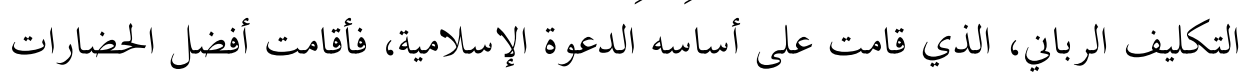
الإنسانية، وأوسعها شمولية، فكانت منهجاً حياتياً. 19

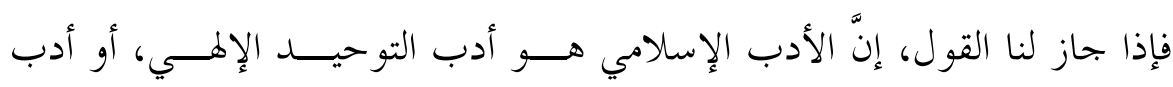

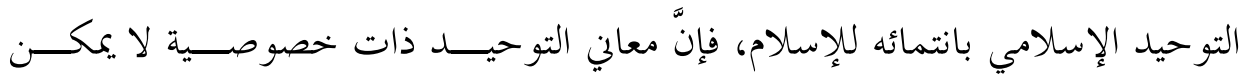

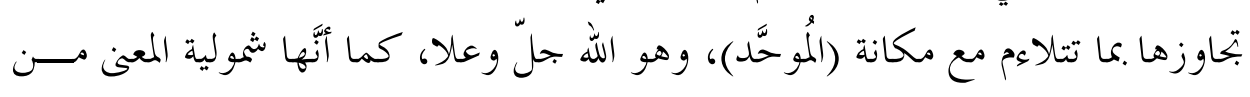

^’ النحوي، عدنان علي رضا. الأدب الإسلامي إنسانيته وعالميته، الرياض: دار النحوي للنشر والتوزيـع، ط؟، صبه. 19 ينظر : قطب، عمد. رؤية إسلامية، بيروت: دار الشروق، صعَا. 
حيث المقتضيات الحياتية التي أقرّها الشرع الإسلامي، لتشمل الحياة الإنسانية الدنيوية

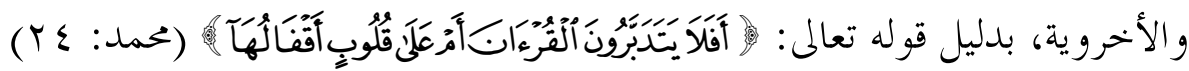

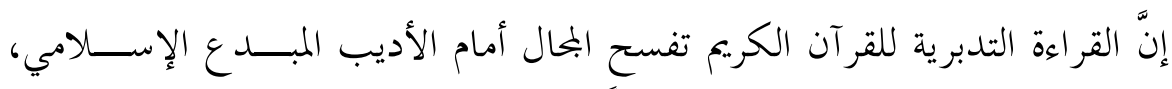

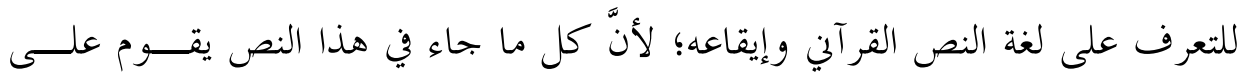

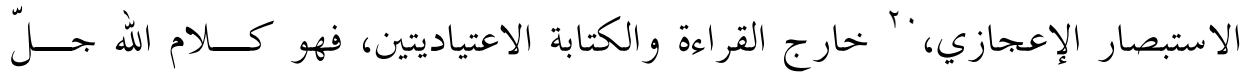

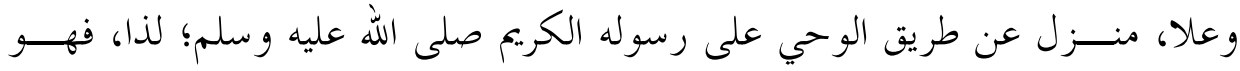

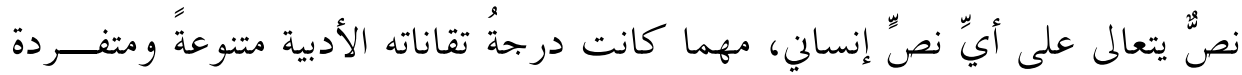
متعالية.

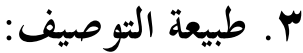

إنَّ طبيعة التوصيف في الأدب الإسلامي هي طبيعة حية، إذا نظرنا إلى الأهـــــاف

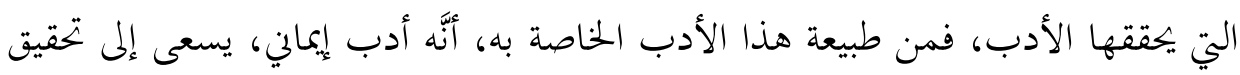

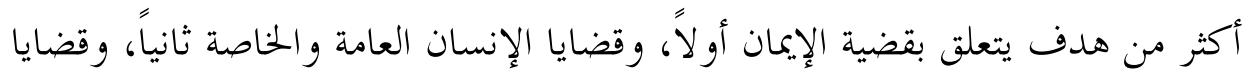

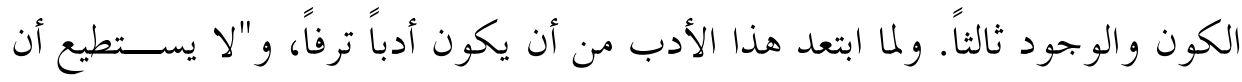

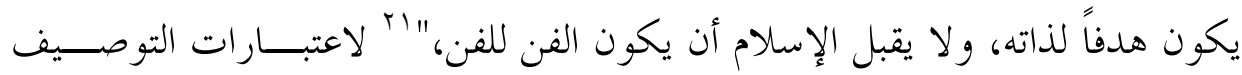

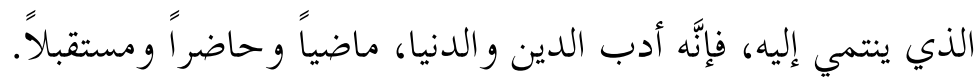

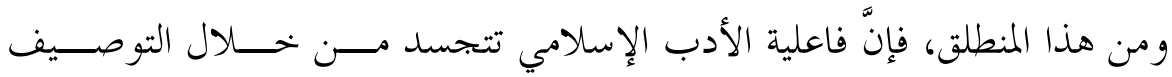

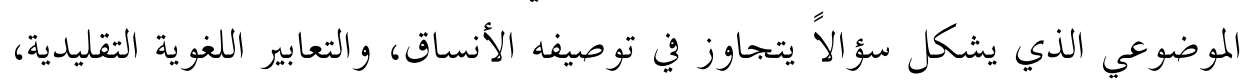

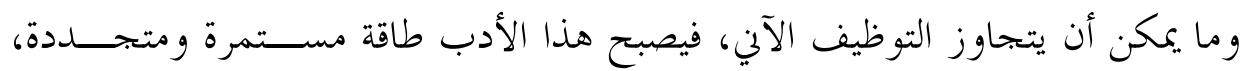

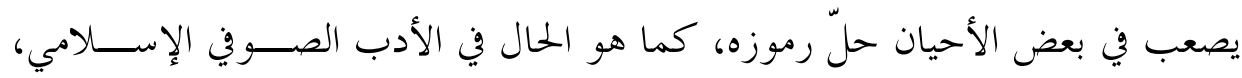

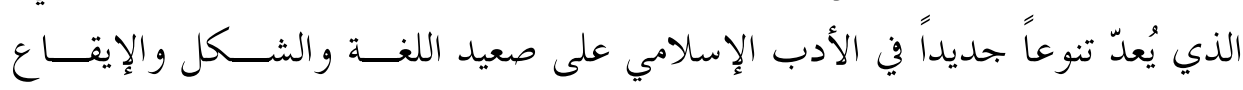

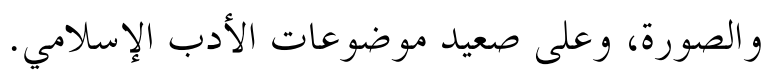

•r ينظر: جمعة، حسين. الثقابل الجمالي في النص القرآني، دمشق: منشورات دار النمير للطباعة والنشر والتوزيع،

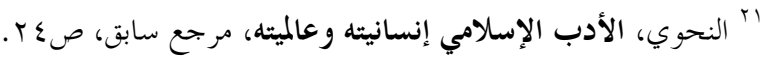




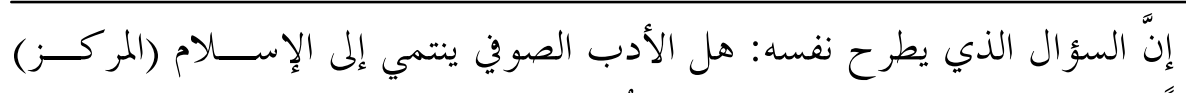

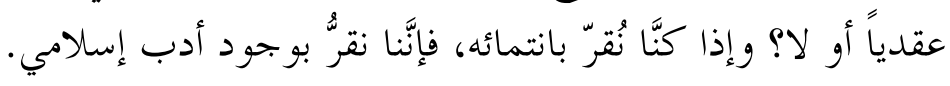

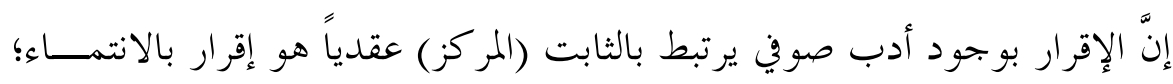

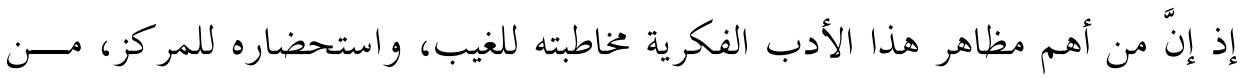

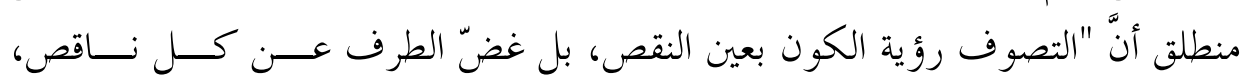

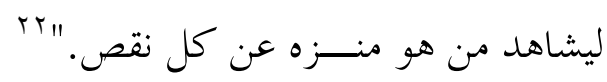

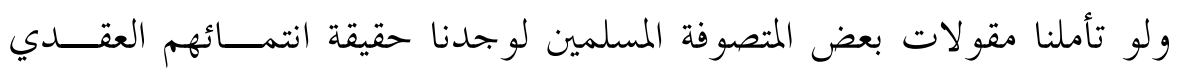

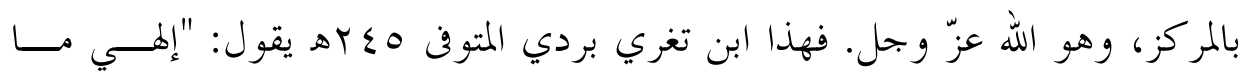

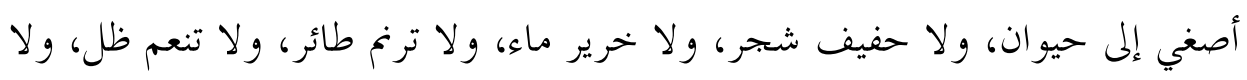

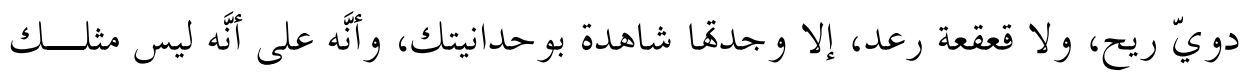

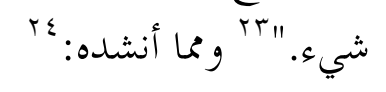

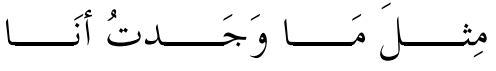

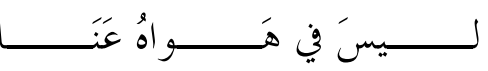

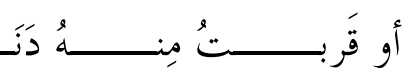

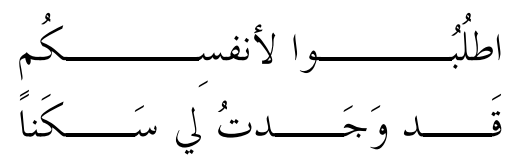

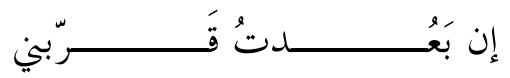

أما أبو حمزة الصوفي، فيُروَى أنَّهَ رفع رأسه إلى السماء، وقال:ror

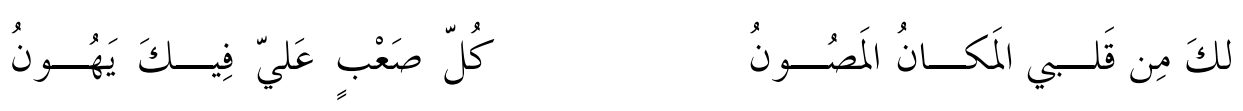

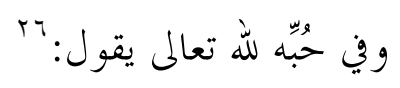

اختـــارَهُم في سَــالف الأزمــانِ

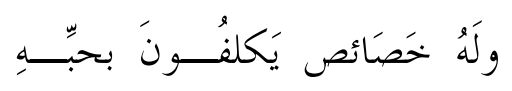

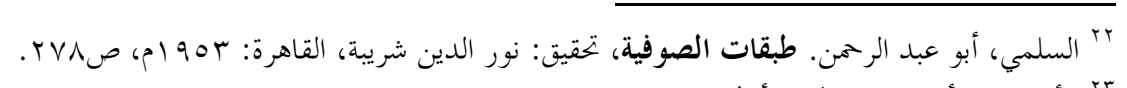

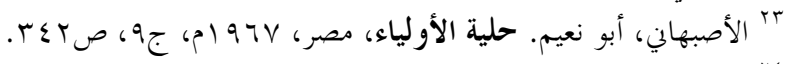

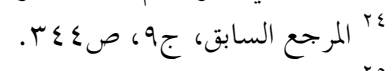

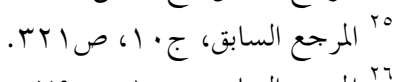

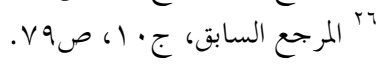




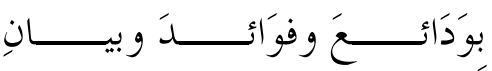

أما الجنيد البغدادي رحمه الله تعالى، وهو من كبار الشيوخ المتصوفة فيقول في حبِّه الله تعالى:

لو شئتَ أطفأتَ عَنْ قَلِبي بِكَ النارا

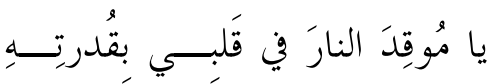

يبدو مما تقدم، أنَّ الأدب الصوفي هو أدب إسلامي المنــزع، نبع من صفاء الإيمان

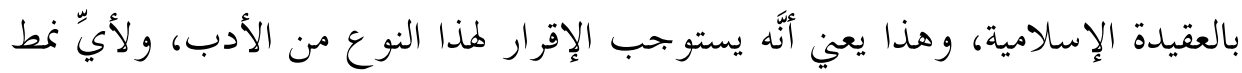

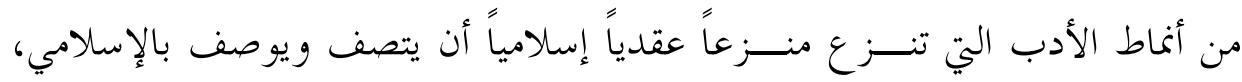

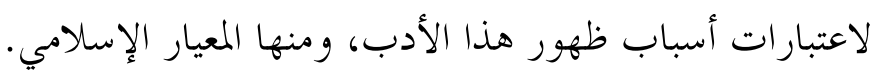

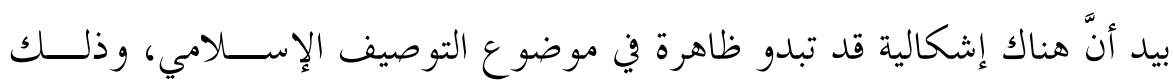

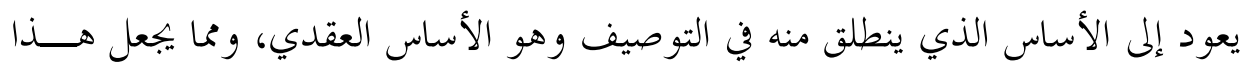

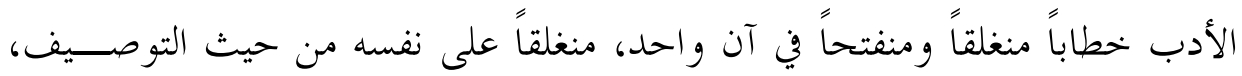

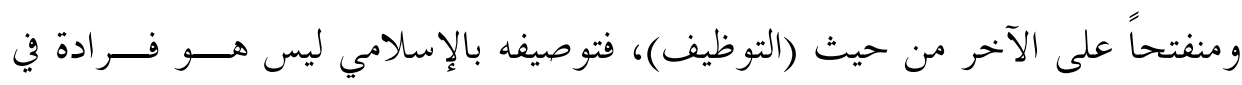

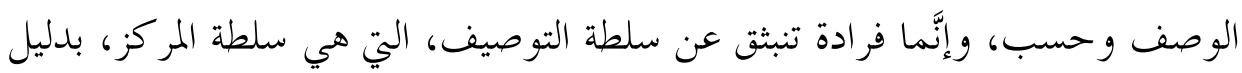

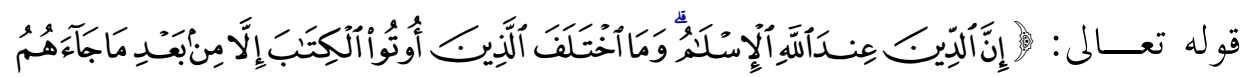

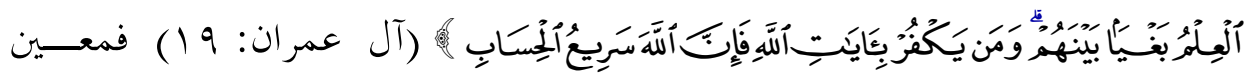
هذا الأدب هو الإسلام بكل محتواه، ومعانيه الدينية والإنسانية.

أمَّا انفتاحه على الآخر، فإنَّ ذلك يعود إلى قدرة الأديب المبدع في إمكانية إيصال

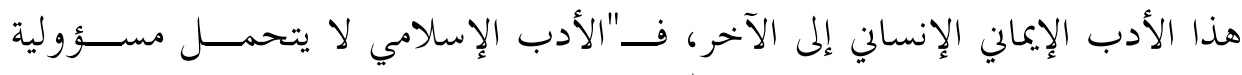

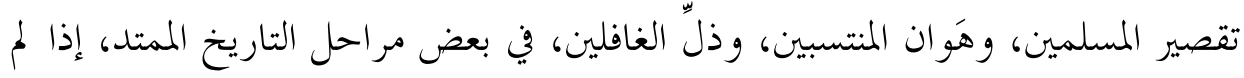

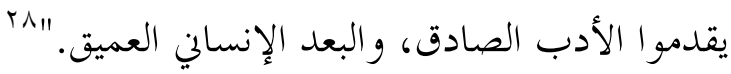

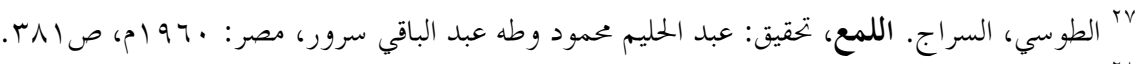

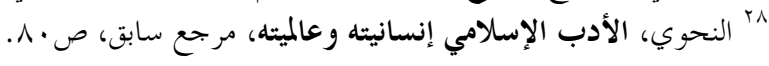




\section{1 ا ـ منهج الأدب الإسلامي وغاياته:}

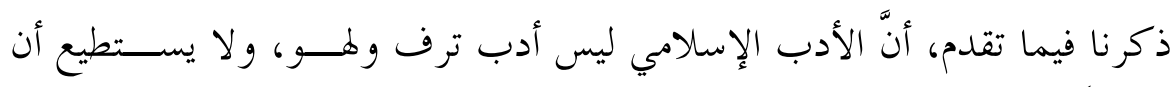

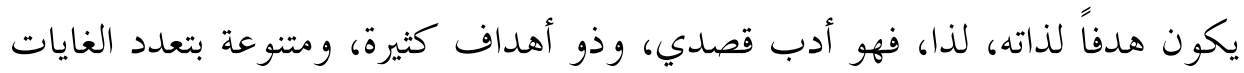

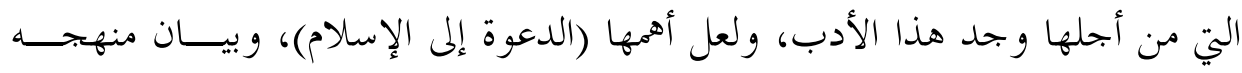
الحياتي، الإنساني الذي يُقرّه، ومعالجته للقضايا الإنسانية معالجة شمولية.

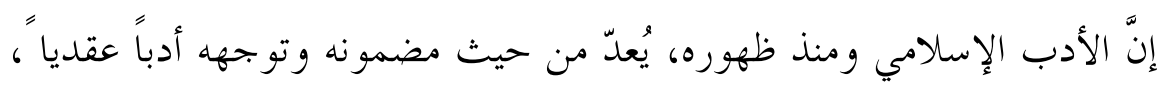
لارتباطه بالعقيدة الإسلامية التي ينطلق منها، و المفاهيم والرؤى الإسلامية التي يعتمدهدها

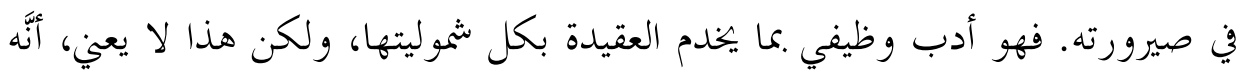

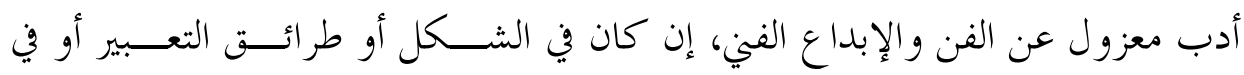

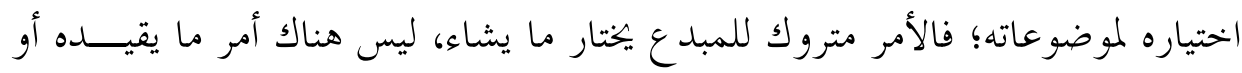

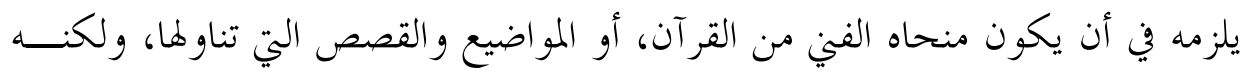

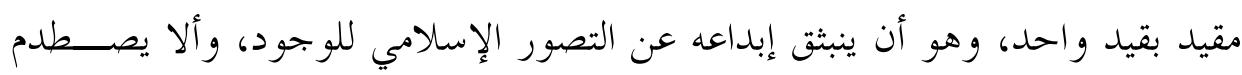

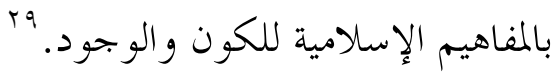

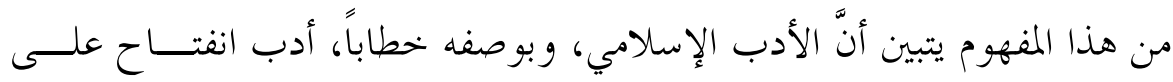

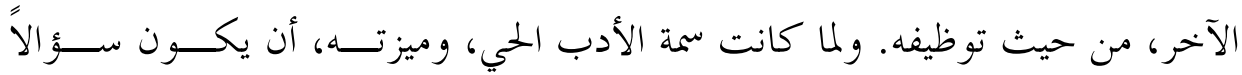

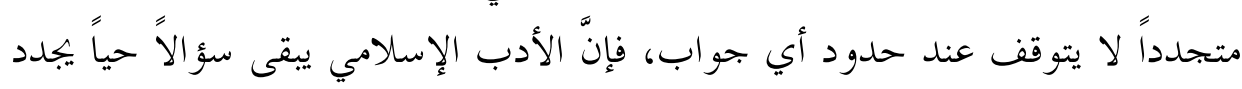

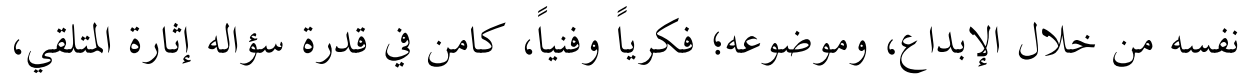

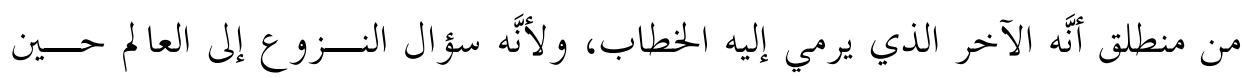

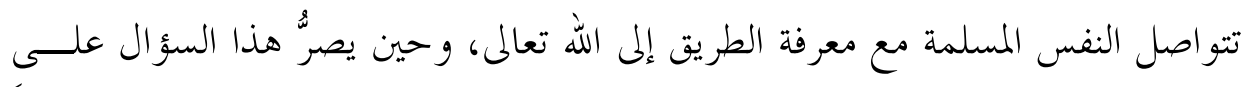

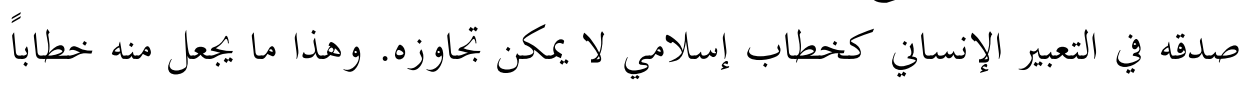

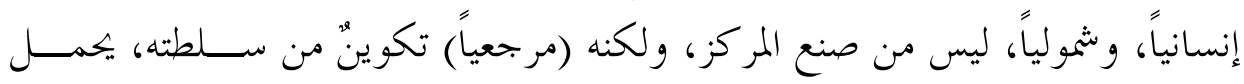


سمات هويته، فهو من صنع إنساني قادر على إبراز الهوية التي ينتمي إليها في صــورقا الإسلامية وفي مضموها.

ولَََّّا كان الأديب المبدع حراً في اختيار موضوعاته، واستخدام أدواته وأشــكاله،

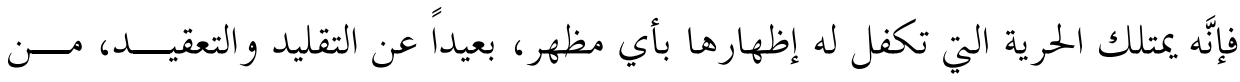

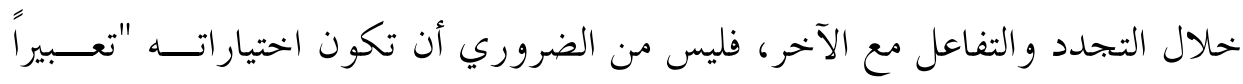

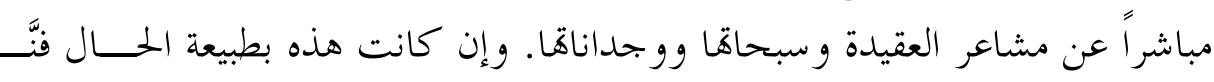

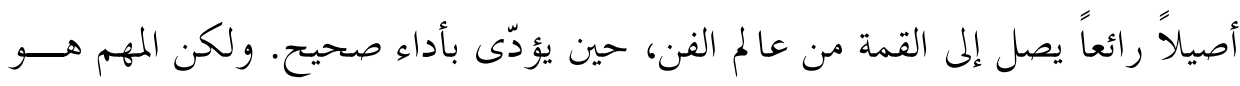

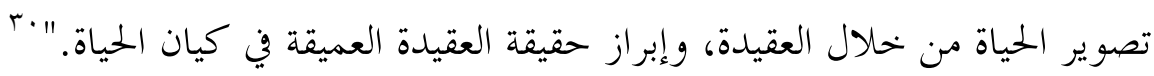

إنَّ أيَّ أدب مهما كان نوعه و جنسه، إنَّما هو مظهر من مظاهر ثقافة الشــعوب،

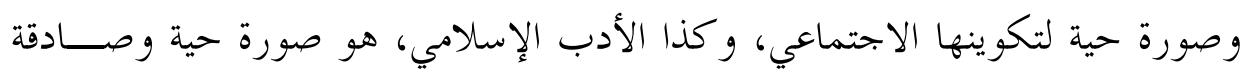

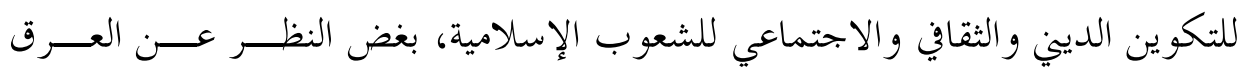

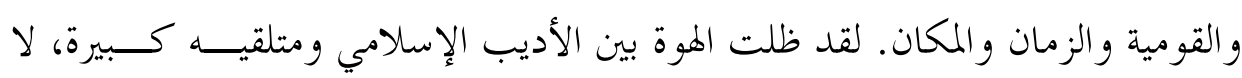
بسبب العقيدة ذاهـا، ولكن بسبب عدم قدرة هذا الأديب من بتحاوز معضلته في تقــــيم

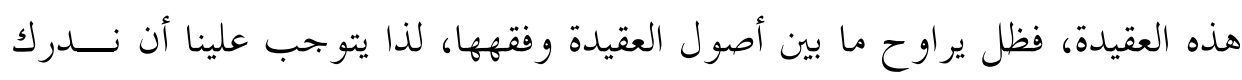
حقيقتين مهمتين: (20) - (20)

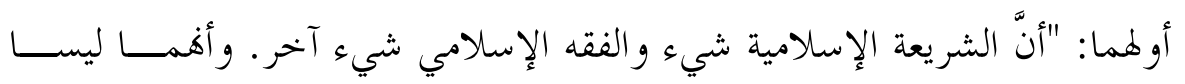

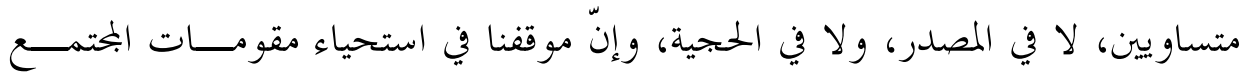
الإسلامي و نظمه منهما ليس و احداً."

ثانيهما: "أنَّ الصورة أو الصور التاريخية للمجتمع الإسلامي، ليست هي الصورة

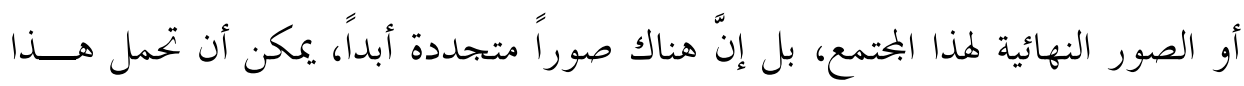

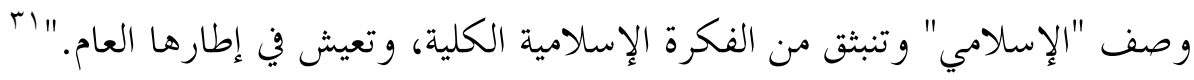




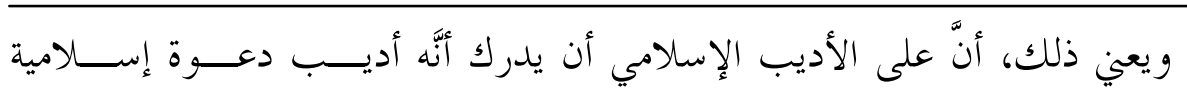

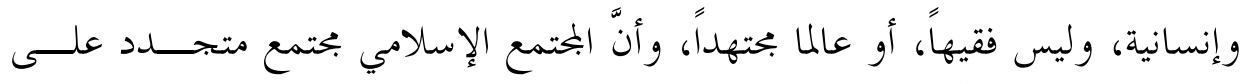

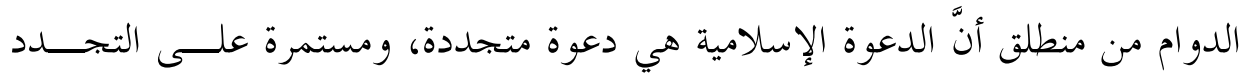
الحياتي مع بقاء الأصول وثباها.

ومن الأمور الملاحظة، والمسجلة على الأدب الإسلامي أنَّه كان وإلى وقت قريب،

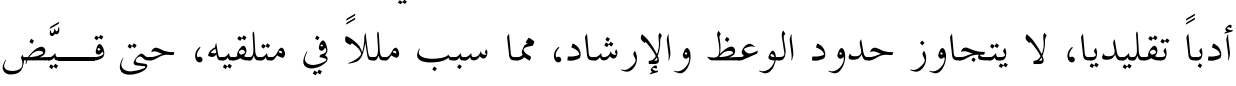

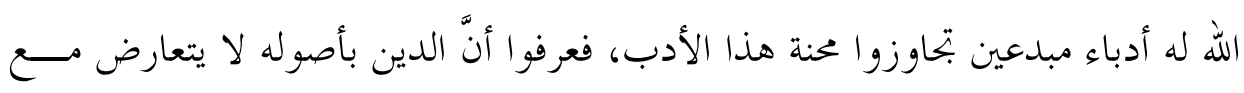
فنِّ الأدب وطرائقه، بُغية توصيل وظيفته بصورة صحيحة، ومقبولة، لكي تكون مؤن مؤثرة في الآخر من قبيل إيصال الدعوة.

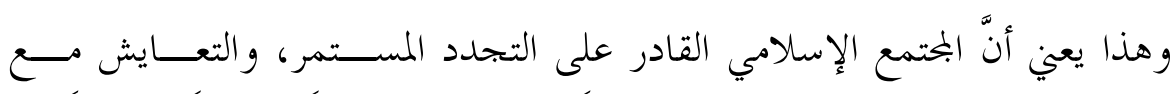

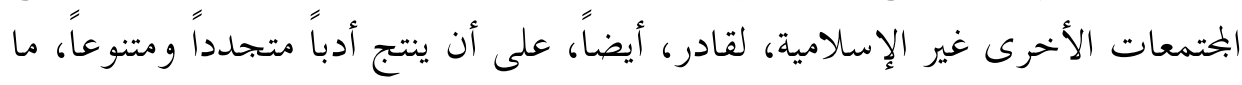

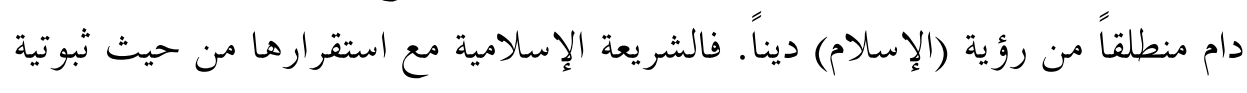

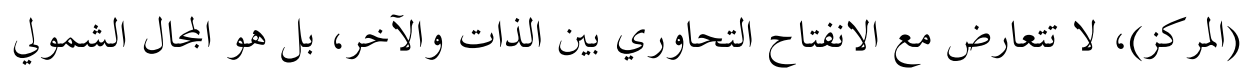

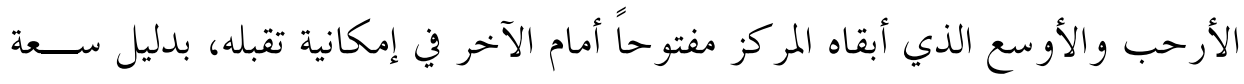
انفتاح الدعوة الإسلامية عليه. فهي لا تؤسس نفسها على اجتهادات الفقه الإسلامي،

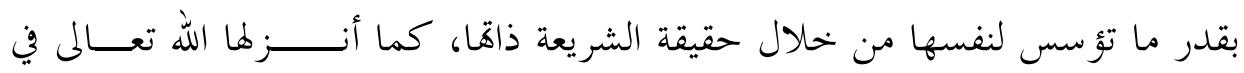

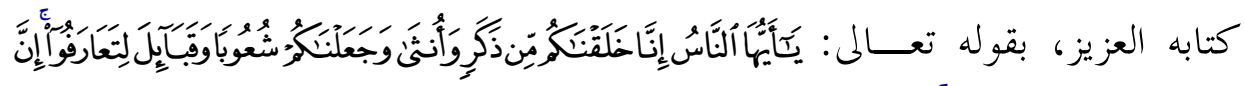

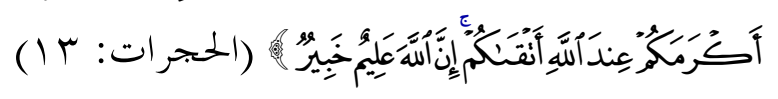

\section{Y. الإبداع وحر كيَّة الأدب الإسلامي:}

إنَّ الشريعة الإسلامية هي بنية معرفية (فوقية)، تتجاوز حدود الكتابـــة الأدبيــة والإبداعية، ولكنها في الوقت نفسه، تمتلك فاعلية حركية كبيرة، تفسح البحال للإبداع

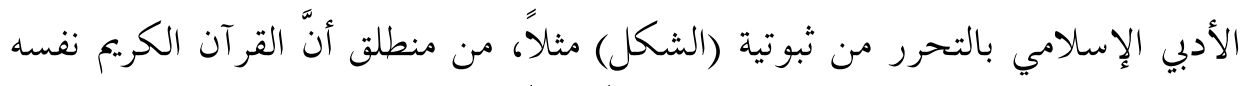

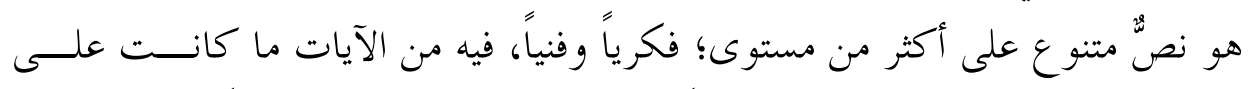

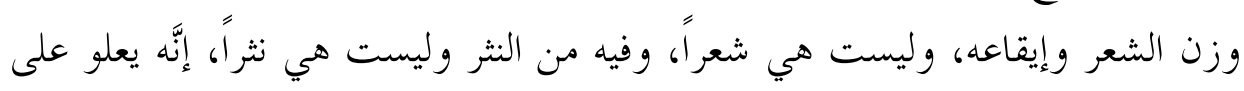




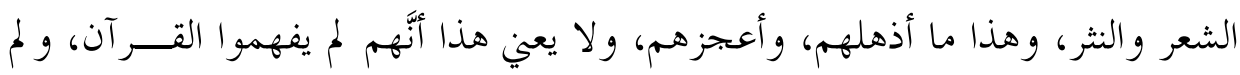

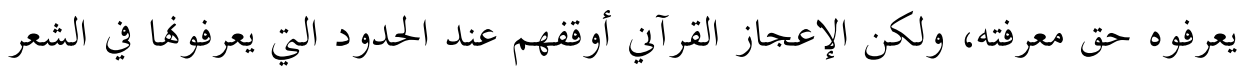

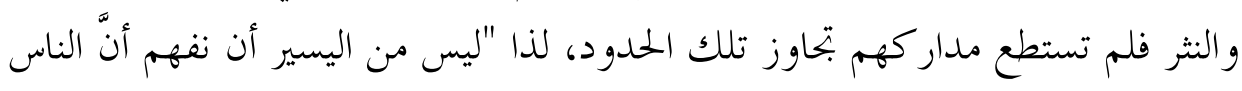

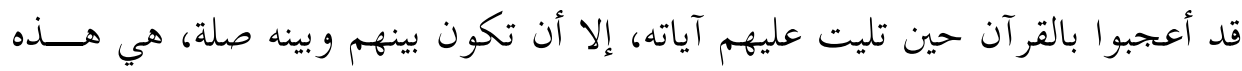

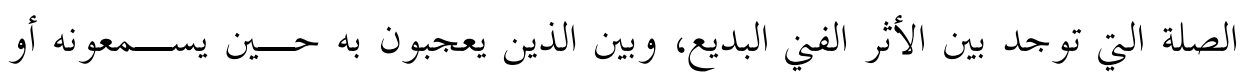

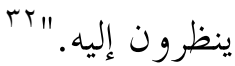

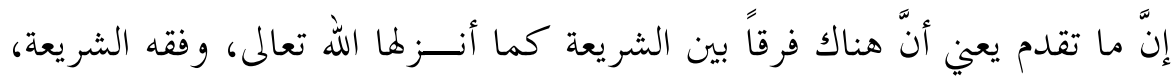

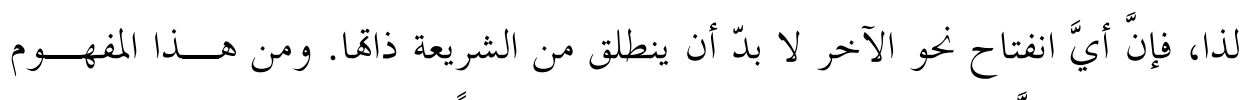

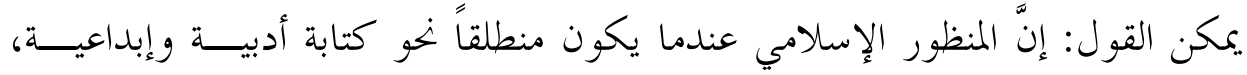

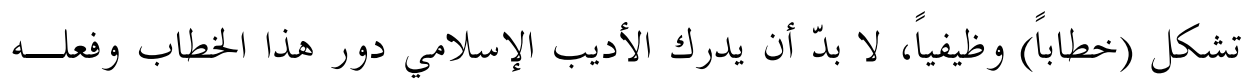

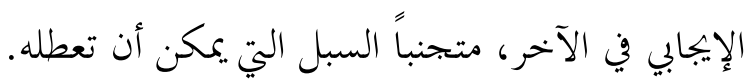

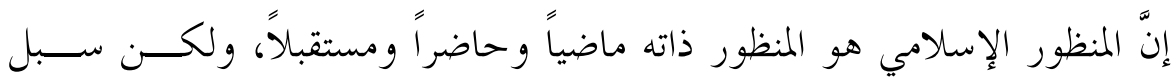
الاتصال و التفاعل قد اختلفت، وهذا أمر طبيعي؛ فحياتنا اليوم لا تشبه حياتنا بالأمس.

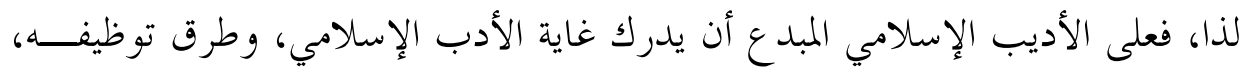

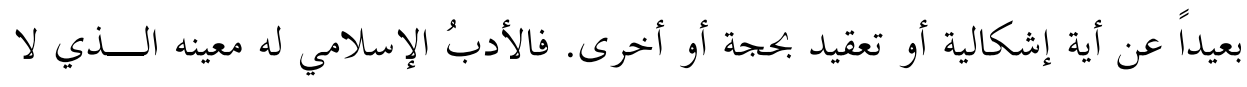

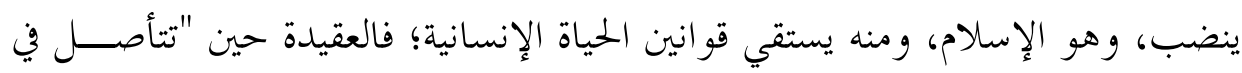

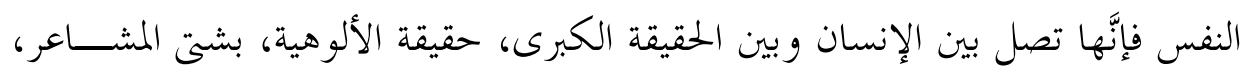

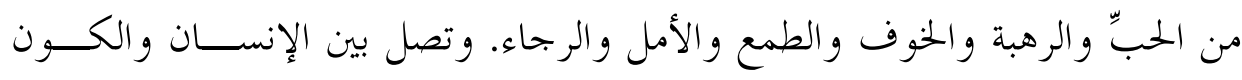

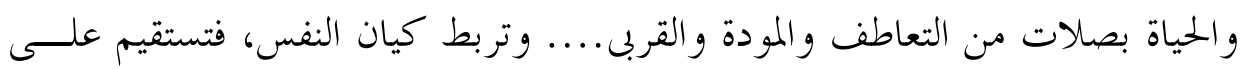

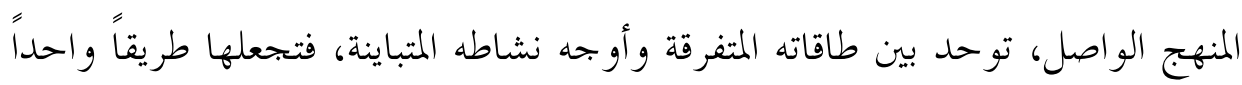
ذا غاية و احدة.

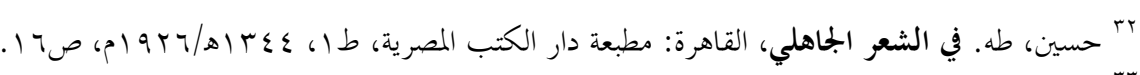

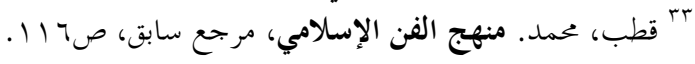


إنَّ حرية الكتابة في واقعها الوظيفي من قبل المبدع الإسلامي، تقابلها حرية القراءة

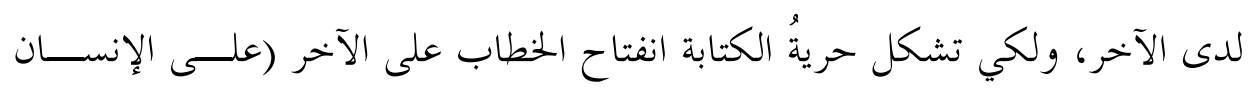
و الواقع والحياة، وعلى الزمان والمكان)، خارجُ حدود اللغة والشكل والإيقاع المكتوب

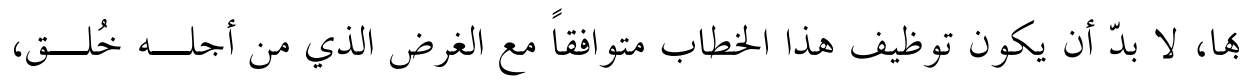

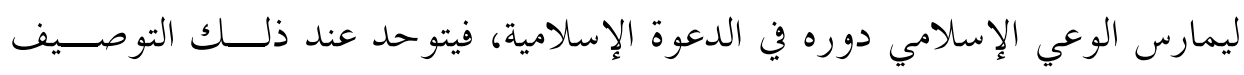

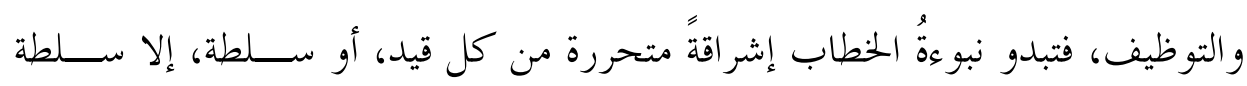

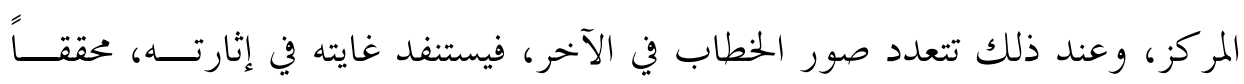
ثنائيته، على أنَّه الأنا في سؤال الآخر، و الآخر في سؤال الأنا، و كل منهما إثارة حقيقية تستفز العقل و الجسد.

خاتمة:

يشكل الأدب الإسلامي، كونه خطاباً، فاعلية لها مصداقيتها في الالتزام العقدي، من كون السلطة التي تنبثق منها هذه الفعالية هي سلطة المركز، و المقصود هـا ســلطة

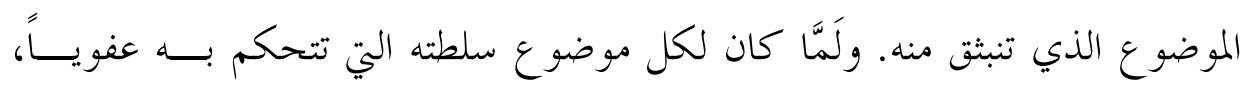
فسلطة الأدب الإسلامي هي الإسلام بكل تفصيلاته وتمركزاته المتعاليــة، المتمثلــــة في

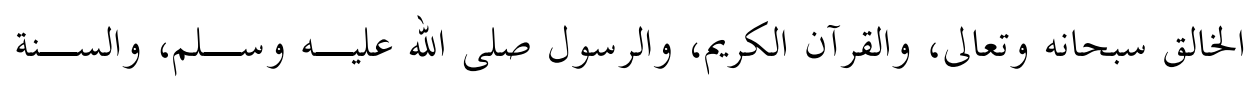
الشر يفة.

ربَّما يخطر ببال الكثير من الأدباء و النقاد أنَّ الأدب الإسلامي شأنه شأن أي أدب

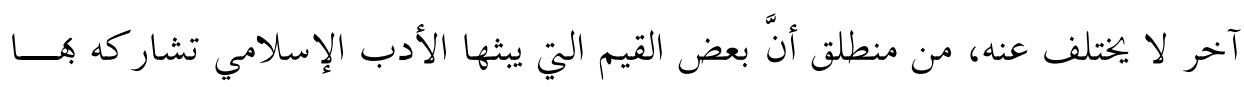

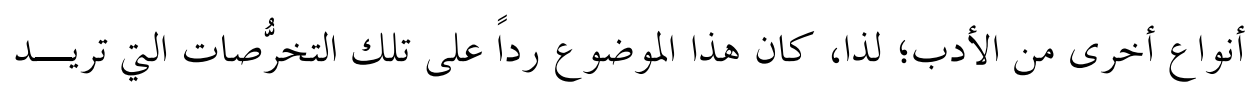

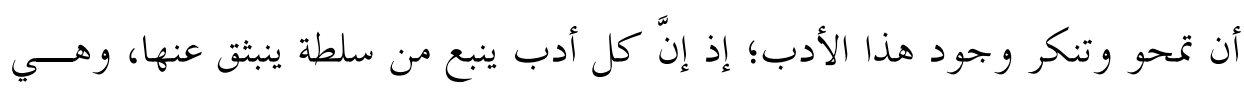




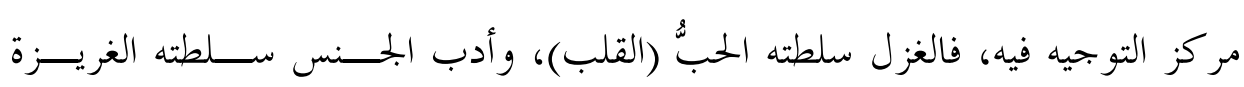
(الجسد)، و هما سلطتان تختلفان اختلافاً جذرياً عن سلطة الأدب الإسلامي. لقد أخذ الأدب الإسلامي مواصفاته وماهيته الخاصة به، التي تفرقه وتميزه عن أيٍ

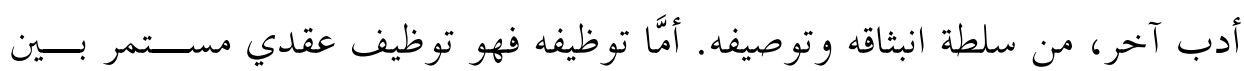

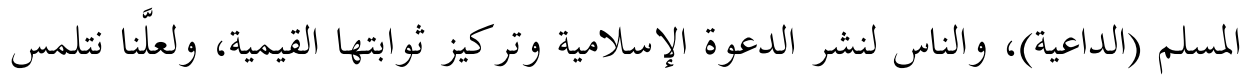

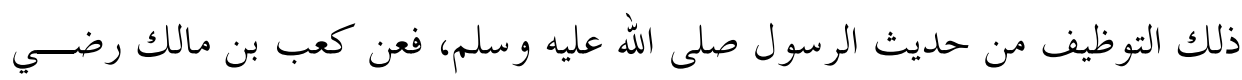

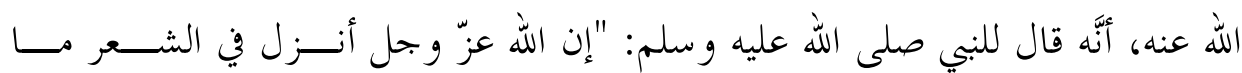

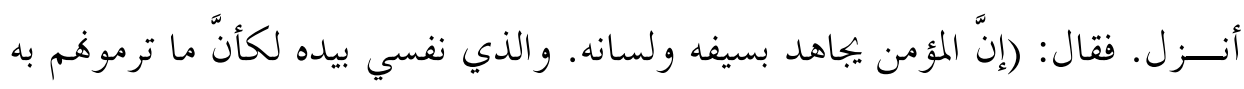
نضح النبل)."

وإذا كانت ثمة تساؤلات تثار حول الإبداع الإسلامي، فنقول: يبقــى الشــكل و المضمون عنصرين ورُكنين متلازمين، وحرية الأديب المسلم في الإبداع الفني لا تلزمه الإنه

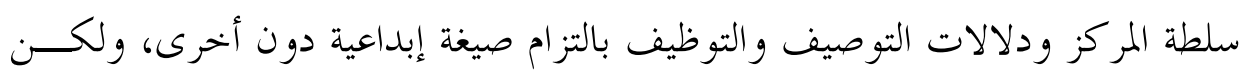

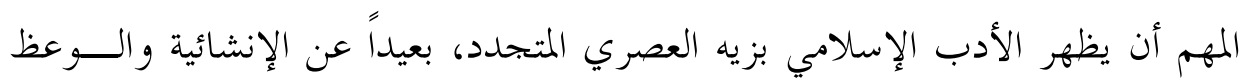
الممل.

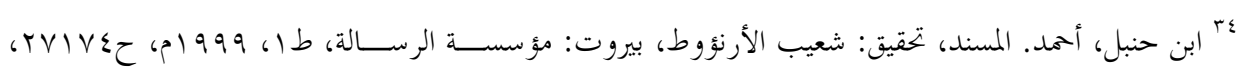

